\title{
Taxonomic monograph of Oxygyne (Thismiaceae), rare achlorophyllous mycoheterotrophs with strongly disjunct distribution
}

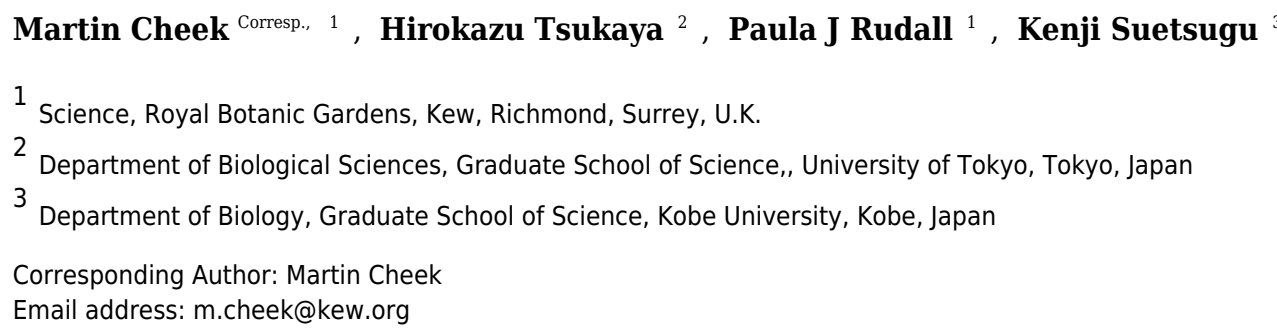

Oxygyne Schltr. (Thismiaceae) is a rare and little-known genus of achlorophyllous mycoheterotrophic perennial herbs with one of the most remarkable distributions of all angiosperm plant genera globally, being disjunct between Japan and West-Central Africa. Each species is known only from a single location, and in most cases from a single specimen. This monographic study names, describes and maps two new species, Oxygyne duncanii Cheek from cloud forest in SW Region Cameroon and O. frankei Cheek from gallery forest in the Central African Republic, representing the first new Oxygyne species described from Africa in 112 years, and raising the number of described Oxygyne species from four to six. Oxygyne duncanii is remarkable for sharing more morphological characters with two of the three Japanese species (O. hyodoi C.Abe \& Akasawa, $O$. shinzatoi (H.Ohashi) Tsukaya) than with the geographically much closer type species of the genus, 0 . triandra from Mt Cameroon. Based mainly on herbarium specimens and field observations made in Cameroon and Japan during a series of botanical surveys, we provide descriptions, synonymy, mapping and extinction risk assessments for each species of Oxygyne, together with keys to the genera of Thismiaceae and the species of Oxygyne. The subterranean structures of African Oxygyne are described for the first time, and found to be consistent with those of the Japanese species. We review and reject an earlier proposal that the Japanese species should be segregated from the African species as a separate genus, Saionia Hatus. The only character that separates the two disjunct species groups is now flower colour: blue or partly-blue in the Japanese species compared with orange-brown in the African species. Studies of the pollination biology and mycorrhizal partners of Oxygyne are still lacking. Two of the six species, $O$. triandra Schltr. and $O$. hyodoi, appear to be extinct, and the remaining four are assessed as Critically Endangered using the IUCN 2012 criteria. To avoid further extinction, an urgent requirement is for 
conservation management of the surviving species in the wild. Since few achlorophyllous mycoheterotrophs have been successfully cultivated from seed to maturity, ex situ conservation will not be viable for these species and protection in the wild is the only viable option. While natural habitat survives, further botanical surveys could yet reveal additional new species between Central Africa and Japan. 
2 Taxonomic monograph of Oxygyne (Thismiaceae), rare

3 achlorophyllous mycoheterotrophs with strongly disjunct

4 distribution

\section{5}

6

7 Martin Cheek $^{1}$, Hirokazu Tsukaya ${ }^{2}$, Paula J Rudall ${ }^{1}$ and Kenji Suetsugu ${ }^{3}$

8

$9 \quad{ }^{1}$ Science, Royal Botanic Gardens, Kew, Richmond, Surrey, U.K.

$10{ }^{2}$ Department of Biological Sciences, Graduate School of Science, University of Tokyo, Tokyo,

11 Japan

$12{ }^{3}$ Department of Biology, Graduate School of Science, Kobe University, Kobe, Japan

13

14 Corresponding author: Martin Cheek, m.cheek@,kew.org

15

16 


\section{ABSTRACT}

18 Oxygyne Schltr. (Thismiaceae) is a rare and little-known genus of achlorophyllous mycoheterotrophic perennial herbs with one of the most remarkable distributions of all angiosperm plant genera globally, being disjunct between Japan and West-Central Africa. Each species is known only from a single location, and in most cases from a single specimen. This monographic study names, describes and maps two new species, Oxygyne duncanii Cheek from cloud forest in SW Region Cameroon and $O$. frankei Cheek from gallery forest in the Central African Republic, representing the first new Oxygyne species described from Africa in 112 years, and raising the number of described Oxygyne species from four to six. Oxygyne duncanii is remarkable for sharing more morphological characters with two of the three Japanese species $(O$. hyodoi C.Abe \& Akasawa, O. shinzatoi (H.Ohashi) Tsukaya) than with the geographically much closer type species of the genus, $O$. triandra from Mt Cameroon. Based mainly on herbarium specimens and field observations made in Cameroon and Japan during a series of botanical surveys, we provide descriptions, synonymy, mapping and extinction risk assessments for each species of Oxygyne, together with keys to the genera of Thismiaceae and the species of Oxygyne. The subterranean structures of African Oxygyne are described for the first time, and found to be consistent with those of the Japanese species. We review and reject an earlier proposal that the Japanese species should be segregated from the African species as a separate genus, Saionia Hatus. The only character that separates the two disjunct species groups is now flower colour: blue or partly-blue in the Japanese species compared with orange-brown in the African species. Studies of the pollination biology and mycorrhizal partners of Oxygyne are still lacking. Two of the six species, $O$. triandra Schltr. and $O$. hyodoi, appear to be extinct, and the remaining four are assessed as Critically Endangered using the IUCN 2012 criteria. To avoid further extinction, an urgent requirement is for conservation management of the surviving species in the wild. Since few achlorophyllous mycoheterotrophs have been successfully cultivated from seed to maturity, ex situ conservation will not be viable for these species and protection in the wild is the only viable option. While natural habitat survives, further botanical surveys could yet reveal additional new species between Central Africa and Japan. 


\section{INTRODUCTION}

48 Oxygyne Schltr. (Thismiaceae-Dioscoreales) is a rare and little-known genus of achlorophyllous mycoheterotrophic perennial herbs. It possesses one of the most remarkable distributions of all angiosperm plant genera globally, being disjunct between Japan and West-Central Africa (Fig. 1). Each species is known only from a single location, and in most cases from a single specimen.

During a series of botanical surveys carried out since 1991 in Cameroon to inform conservation management (Cheek \& Cable, 1997), identification of collected specimens has resulted in the discovery of many species that are new to science, including a new species of Oxygyne Schltr. (Thismiaceae), previously designated as Oxygyne sp. nov. (Thomas \& Cheek, 1992; Cheek et al., 1996; Cheek \& Ndam, 1996; Cheek \& Williams, 2000; Cheek, 2006; Sainge et al., 2010). Here, this specimen is formally named as Oxygyne duncanii Cheek, representing the first new African Oxygyne described for 112 years. This new species is remarkable for characters that are otherwise unknown in the sole previously known African species $(O$. triandra Schltr.) but which do occur in two of the three Japanese species (O. hyodoi C. Abe \& Akasawa, O. shinzatoi (H.Ohashi) Tsukaya ). In the course of finalizing this paper, material of a third African Oxygyne came to light, formally named here as $O$. frankei Cheek. Its morphological affinities are with the type species, $O$. triandra. In this monographic study, we present a detailed survey of all described species of Oxygyne, including mapping and extinction risk assessments for each species, together with a species key.

Although some earlier authors (Jonker, 1938; Maas-van der Kamer, 1998) placed

Thismia and its allies (including Oxygyne) as a tribe Thismieae within the family Burmanniaceae sensu lato, recent molecular phylogenetic data (Merckx et al., 2006) strongly indicate that Thismiaceae are best placed as a separate family. These relatively well-sampled analyses place Thismiaceae as sister to Taccaceae, in a different subclade of Dioscoreales from Burmanniaceae sensu stricto. Furthermore, the two families are separated from each other by numerous morphological characters, as follows:

Burmanniaceae: Perianth long-cylindrical, only the upper portion detaching in fruit;

74 stigma and stamens positioned at throat of tube; stamens 3 , sessile, anther cells lateral on broad central connective; stigmas often cupular; annulus absent; ovary septal nectaries present; ovary 3-locular, or 1-locular. 
Thismiaceae: perianth cup-like or campanulate, rarely shortly cylindrical, detaching in fruit at base of perianth tube; stigmas inserted in basal $1 / 4$ to $1 / 2$ of perianth tube; stamens inserted at mouth of tube, or deep inside tube; stamens 6 (3 in Oxygyne), on long filaments; anther cells collateral, not separated by connective; stigmas lobed; annulus present at mouth of tube or deep inside (except Tiputinia and Haplothismia); ovary septal nectaries absent; ovary 1-locular. Oxygyne differs from other Thismiaceae in some respects, notably in possessing only three stamens; it has therefore been included in either Burmanniaceae or Thismiaceae. However, in his monograph of Burmanniaceae, Jonker (1938) considered Oxygyne to be closer to Thismieae (today's Thismiaceae), stating “... This important genus, of which unfortunately only one species and one specimen is collected .... shows the normal flower construction of the Thismieae: perianth urceolate to campanulate, style short and thick with three stigmas, ovary with three free stalked placentas (as in Thismia), but has only three stamens, while all other genera of Thismieae possess six stamens. A one-celled ovary and three stamens are the characteristics of the tribe Apterieae, but that tribe always shows quite another construction of the flower. The genus Oxygyne is therefore a link between the somewhat isolated Thismieae and the other tribes of the Burmanniaceae. For this reason I do not agree with Hutchinson's view to class the Thismieae as a separate family..." (Jonker, 1938: 47). However, more recent molecular data have supported Hutchinson's conclusion (e.g. Yokoyama et al., 2008; see below and Fig. 2).

\section{MATERIAL AND METHODS}

The electronic version of this article in Portable Document Format (PDF) will represent a published work according to the International Code of Nomenclature for algae, fungi, and plants (ICN), and hence the new names contained in the electronic version are effectively published under that Code from the electronic edition alone. In addition, new names contained in this work which have been issued with identifiers by IPNI will eventually be made available to the Global Names Index. The IPNI LSIDs can be resolved and the associated information viewed through any standard web browser by appending the LSID contained in this publication to the prefix "http://ipni.org/". The online version of this work is archived and available from the following digital repositories: PeerJ, PubMed Central, and CLOCKSS. 
109 Nomenclatural changes were made according to the Code (McNeill et al., 2012). Names of 110 species and authors follow IPNI (continuously updated). Regarding the Cameroonian species, 111 this study is partly based on herbarium specimens and field observations made in Cameroon 112 during a series of botanical surveys beginning in 1991. These surveys were mainly led by the

113 first author. So far, they have resulted in 52,450 specimens being studied at $\mathrm{K}$ and YA, of which

11437,850 were newly collected, the data stored on the Kew Cameroon specimen Access database

115 (Gosline, p. 11 in Cheek et al., 2004). The methodology used is reported in Cheek \& Cable

116 (1997). The top set of specimens was initially deposited at SCA, and later YA, duplicates being

117 sent to K. The fieldwork was approved by the Institutional Review Board of the Royal Botanic

118 Gardens, Kew entitled the Overseas Fieldwork Committee (OFC). The most recent OFC

119 approval is numbered 807. The most recent invitation to effect research on the flora and

120 vegetation of Cameroon has the reference number 050/IRAD/DG/CRRA-NK/SSRB-

$121 \mathrm{HN} / 09 / 2016$. It is issued under the terms of the 5 year Memorandum of Collaboration between

122 Institute for Research in Agricultural Development (IRAD)-Herbier National du Cameroun and

123 Royal Botanic Gardens, Kew signed 5 ${ }^{\text {th }}$ Sept 2014.

The morphological species concept was followed in defining species (each species being separated from its congeners by several, usually qualitative, morphological disjunctions), and the overall morphology of species was described and illustrated following standard botanical procedures as documented in Davis \& Heywood (1963). All specimens cited have been seen by one or more of the authors unless indicated 'n.v.' Herbarium citations follow Index Herbariorum (Thiers et al., continuously updated) and binomial authorities IPNI (continuously updated). Material of the suspected new species was compared morphologically with material of all other species of Oxygyne globally, which is contained at mainly at B, BM, FU, K, P, SCA TI and TNS. made using the categories and criteria of $I U C N$ (2012). Herbarium material was examined with a Leica Wild M8 dissecting binocular microscope. This was fitted with an eyepiece graticule

136 measuring in units of $0.025 \mathrm{~mm}$ at maximum magnification. The drawing was made with the 137 same equipment using Leica 308700 camera lucida attachment. Google Earth was used to 
138 georeference specimen points for mapping purposes. Specimen points were located on imagery

139 from the metadata provided and latitude and longitude read-off from Google Earth.

140 For light microscope observations of root anatomy (Fig. 3), fixed material was sectioned

141 using standard methods of Paraplast embedding and serial sectioning (6-12.5 um thickness) with

142 a Reichert Jung 2040 rotary microtome. Sections were stained in safranin and Alcian blue and

143 mounted in DPX. Photomicrographs were taken using a Leitz Diaplan photomicroscope (Leitz,

144 Germany).

146 TAXONOMIC TREATMENT

147 Thismiaceae J. Agardh, nom. cons. (Agardh, 1858: 99)

149 Type genus: Thismia Griff. (Griffith, 1845: 221)

150 Achlorophyllous mycoheterotrophs; for family description see Stevens (2001 onwards).

151 Five genera, c. 55 species, mostly rare and narrowly endemic; overall distribution widely

152 scattered, mostly in the tropical and subtropical forests of South America, Africa and Southeast

153 Asia but extending into the temperate zone; in Africa with highest concentration of species in

154 Cameroon (Sainge et al. 2017).

155

156 Key to genera of Thismiaceae

1. Staminal filaments inserted at the mouth of the perianth tube, erect and exserted at base, then arching inwards, the anthers held at the level of the tube mouth, or just inside

161

Staminal filaments inserted deep inside the perianth tube, or (Thismia) in the throat, but

2. Stamens 6, annulus absent; anthers lacking a flat elliptic connective from which the thecae depend. 

connective. Africa and

4. Annulus inserted deep inside the perianth tube; stamens inserted below the annulus; anthers adnate to stigma; rhizomes with clusters of spherical tubers. Continental Africa Afrothismia

\section{9} Africa... Annulus inserted at mouth of perianth tube; staminal filaments adjacent to annulus; anthers free, not touching stigma; rhizomes tuberous or not, but never with clusters of spherical bulbils. Americas, AsiaAustralasia. Thismia

\section{Oxygyne Schltr. (Schlechter 1906)}

Type species: Oxygyne triandra Schltr.

Achlorophyllous mycoheterotrophs, glabrous, flowers held just above the substrate

191 (1-)3-6, vermiform, radiating from the base of the rhizome, rarely branched and then articulated 192 at the junctions, c. $1 \mathrm{~mm}$ diameter, lacking root hairs, surface papillate. Stems rhizomatous, 1-3

193 per plant, white, \pm erect, unbranched, terete, 1-1.5 mm diam; scale-leaves inserted spirally, 2-3

194 on the upper half of the rhizome, translucent, oblong or lanceolate, obtuse.

195 Inflorescences 1-2(-5)-flowered, bracts 3, in one whorl, equal, erect, subtending the

196 flower, oblong-triangular, slightly convex, becoming accrescent and valvate around the fruit.

197 Flowers bisexual, actinomorphic, blue, blue-green, blue-white or orange-brown, erect, 5-10 mm

198 wide, perianth tube campanulate, lacking ridges; perianth lobes 6(-8), the three outer and 3 inner 
199 lobes equal and at anthesis appearing as if in a single whorl, inserted at rim of perianth tube,

200 patent (or slightly ascending or erect, but possibly only as an artefact of preservation), narrowly

201 triangular in outline and flattened, or filiform, variously ornamented or not.

202 Androecium with 3(-4) stamens inserted at mouth of perianth tube, opposite the outer

203 perianth lobes. Filaments ascending at base, then arching down into the perianth tube, terete or

204 flattened, and with or without appendages; anthers basifixed, extrorse, thecae \pm elliptic,

205 collateral, longitudinally dehiscent, inserted on the lower surface of a circular-elliptic connective,

206 free. Annulus (or taenia) inserted immediately below the stamens, occluding the mouth of the

207 perianth tube apart from a central pore and/or 3 apertures through which the stamens are

208 inserted; composed of separate, connivent or united subquadrangular lamellae, each opposite the

209 inner perianth lobes; lamellae absent (O. triandra, O.shinzatoi, O.duncanii) or present (O.

210 yamashitae, O.hyodoi) opposite the outer perianth lobes; lamellae with appendages or central

211 aperture or not.

212 Ovary white, campanulate, unilocular, placentae 3, either (O. triandra) "about three times

213 the length of the placenta-stalks" (Jonker 1938: 261) or (O.duncanii) clavate, the stipe attached

214 distally near the junction with the floor of the perianth tube, placental heads dilated, with

215 multiple ovules. Style-stigma $1 / 4$ to $1 / 2$ the length of the perianth tube, style terete, style-

216 head/stigma with 3-angled or lobed head, and with 3 lateral lobes, the lobes erect acute, entire or

217 bifurcate, or globose (O. triandra and O. frankei with three subulate lobes only, without lateral

218 lobes).

219 Fruit almost enveloped by the three membranous, valvate, accrescent bracts; perianth

220 falling above the base of the perianth tube. Fruiting ovary translucent-white, narrowly

221 cylindrical-campanulate, apex truncate (floor of the perianth tube) developing an aperture by

222 deliquescence, with a ragged margin. Seeds numerous, ovoid, lacking wings or elaiosomes,

223 epidermal cells convex (O. frankei). Six species.

224

225 Phenology: Flowering in (July-)October.

226 Distribution \& habitat: SW Region of Cameroon, Central African Republic, and southern

227 Ryuku islands and southern mainland of Japan. Known from evergreen forest close to the ocean

228 in mountainous areas with rainfall $>2500 \mathrm{~mm}$ p.a. (excepting $O$. frankei); 180-1300m alt. 
229 Etymology: meaning sharp female organs, referring to the acute, prong-like styles of the type 230 species.

231 Local name: various in Japan, none known in Africa ${ }_{x x}$

232 Conservation: all species are Critically Endangered according to IUCN 2012 criteria, except for $233 O$. triandra and $O$. hyodoi which seem to be globally extinct.

Pollination has not been intensively investigated either in the Cameroon species $(O$. duncanii, this paper) or the Japanese species (e.g. O. yamashitae: Yahara \& Tsukaya, 2008). However, unidentified small dipterans were recorded as the floral visitors of $O$. yamashitae (Suetsugu, personal observations 2015), as in Afrothismia (M. Cheek, personal observations 2007). No scent has been detected in the flowers of the Cameroon species $O$. duncanii (this paper) or the Japanese species (e.g. O. yamashitae: Yahara \& Tsukaya, 2008). splash-cup mechanism as reported for Thismia by Maas-van der Kamer (1998). This inference is supported by the reported presentation of the fruits, which are held erect and have terminal openings. However, subsequent or alternative dispersal of seeds by ants, as occurs in Sciaphila (Suetsugu et al., 2017) or even by camel crickets, as occurs in other Japanese mycoheterotrophs (Suetsugu, 2017) cannot be entirely ruled out. Elaiosomes, which occur in Afrothismia (Cheek, 2009), are not seen in the only species of Oxygyne in which seeds have been reported, namely $O$. frankei (this paper).

Root anatomy was examined here in $O$. duncanii (Fig. 3). Roots show the "typical" monocot structure (e.g. Kauff et al., 2000), with a single-layered epidermis enclosing a cortex and central vascular strand. The cortex is parenchymatous, and the outermost layer of the cortex is not differentiated into a dimorphic hypodermis, as in some other monocots. Many of the cortical cells contain enlarged coiled fungal hyphae, which are also visible in some epidermal cells. Similar structures are also reported in other Thismiaceae (Afrothismia) and Burmanniaceae (Imhof et al., 2013).

No species of Oxygyne has yet been studied for fungal associates, but we speculate that the fungal partners of Oxygyne are likely to be arbuscular mycorrhizal (AM) fungi of the phylum 258 Glomeromycota, as in other Thismiaceae. Most notably, Afrothismia has highly specific 
259 interactions with Rhizophagus fungi (Franke et al., 2006; Merckx \& Bidartondo, 2008; Gomes et 260 al., 2016; Merckx et al., 2017).

261 Cultivation of Oxygyne has not yet been reported and is unlikely to be successful since it

262 has been rarely achieved for any other obligate mycoheterotrophic vascular plant (but see

263 Yagame et al., 2007).

264 Chromosome numbers have been reported as $2 n=18$ in O. shinzatoi (Tsukaya et al., 265 2007).

266 Two of the three African species occur or occurred in the Cross-Sanaga River interval, 267 including western Cameroon. This region is the most species-diverse per degree square 268 documented in tropical Africa; it includes several Pleistocene refuge areas (Cheek et al., 2001) 269 and has been documented as a centre of plant diversity (Cheek et al. 1994). The Japanese species 270 also occur (or occurred) in the species-diverse forests of Japan (Yahara \& Tsukaya, 2008;

271 Suetsugu \& Fukunaga, 2016).

272 In terms of phylogenetic placement within Dioscoreales, molecular analysis using $18 \mathrm{~S}$

273 rDNA (Yokoyama et al., 2008) placed O. shinzatoi within the Thismia clade (Thismieae or

274 Thismiaceae), most likely as sister to all other species of Thismiaceae (see Fig. 2, also Merckx \& 275 Smets, 2014). Morphological analysis (Merckx \& Smets, 2014) found that Thismia is 276 paraphyletic with respect to Tiputinia, Haplothismia, and Oxygyne, though with low branch 277 support. Our observations of comparative morphology indicate a close affinity for Oxygyne with

278 Tiputinia and Haplothismia, which share staminal filaments inserted at the mouth of the perianth 279 tube which are initially erect, and later arch into the mouth of the tube. They also share six 280 identical perianth lobes in which there is no differentiation between the outer and inner perianth 281 whorl. It is possible that the lamellae that form the annulus in Oxygyne are homologous with the 282 stamens opposite the inner perianth whorl in Tiputinia and Haplothismia. The globose structures 283 at the base of the staminal filament in $O$. duncanii and the marginal teeth of the flattened 284 staminal filaments of O. yamashitae could be homologous with similar structures in Tiputinia 285 foetida. All species of Oxygyne share with the single species of Haplothismia anthers in which 286 the two linear, collateral anther thecae depend from the midline of one face of a flat elliptic 287 connective. 
In this monograph, under the species entries below, we discuss taxonomic affinities based on morphology, but we choose not to erect any formal infrageneric groupings since so many gaps remain in our knowledge of the taxa recognized.

\section{Identification key to species of Oxygyne}

295

1. Flowers blue-white or blue-green. Japan

2. Staminal filaments strongly dorsiventrally flattened, subfoliose, margins deeply toothed; terminal style-stigma with three acute branches, style appendages each bifurcate, apices acute 1. O. yamashitae

3. Perianth lobes filiform; base of lobes with callus-like cluster of round cells on the adaxial

Staminal filaments subcylindrical, margins entire; style-stigma and style appendages with apices clavate or capitate, rounded 
318 Perianth lobes white, c. $5 \mathrm{~mm}$ long; tube dark green, base orange brown.

Holotype: Japan, Kagoshima Prefecture, Yaku Island, along western branch of Futamata River, fl. 24 Oct. 2007, K. Fuse, H. Yamashita \& H. Ikeda s.n. (Holotype FU! Herbarium specimen, isotypes TI! Herbarium specimens) (Figs. 1 and 4)

Saionia yamashitae (Yahara \& Tsukaya) H. Ohashi (Ohashi 2015:17). Homotypic synonym.

Small, achlorophyllous mycoheterotroph. Roots $1-5$, creeping, c. $0.5-1 \mathrm{~cm}$ long. Stem simple or branched, erect, glabrous, less than $1 \mathrm{~cm}$ tall. Inflorescence stem short, c. $1 \mathrm{~mm}$ in diameter, racemose, 1- or 2(or 3)-flowered, bearing scale-like bracts, white. Bracts at base of flowers, 3 or more, $1 \mathrm{~mm}$ long, lanceolate, white. Flowers October, upright or inclined, pale blue, glabrous, c. $5 \mathrm{~mm}$ long, $5 \mathrm{~mm}$ in diameter; perianth united, 6(-8) lobed at apex, tube campanulate, c. $3 \mathrm{~mm}$ long; perianth lobes pale blue, narrowly triangular, elongated, c. $2 \mathrm{~mm}$ long, resembling a star; each perianth lobe having a lamella at throat; lamella convex, inflexed, united, forming an annular corona having a hole in centre; lamella of each outer perianth lobe having a slit in which a stamen is bent inward torward the stigma; lamella of each inner perianth $1 \mathrm{~mm}$ long, $0.7 \mathrm{~mm}$ wide, trapezoid, ended in a sharply bifurcated tip with two lobes $0.3 \mathrm{~mm}$ long. Stamens $3(-4)$, attached to base of outer perianth lobes; each filament inflexed, having two pairs of projections at base, bearing an anther at tip. Anthers pale yellow, bithecal, $0.5 \mathrm{~mm}$ long. Style 1, $1.3 \mathrm{~mm}$ long, thick, having 3 short, triangular stigmas, $0.25 \mathrm{~mm}$ long, $0.2 \mathrm{~mm}$ wide at base, surrounded with 3 dichotomous appendages. Stalks of appendages c. $0.15 \mathrm{~mm}$ long, bearing two unequalsized branches elongated oppositely to each other along longitudinal axis of stigma; upper branches longer, pointed, c. $0.5 \mathrm{~mm}$ long, c. $0.1 \mathrm{~mm}$ in diameter; lower branches short, club-

345 shaped, c. $0.15 \mathrm{~mm}$ long, c. $0.15 \mathrm{~mm}$ in diameter. Ovary c. $1 \mathrm{~mm}$ long, white. Ovules many 346 (from Tsukaya 2016).

347 Phenology: Flowering in October. 
348 Distribution \& habitat: known only from Yaku Island, formerly at two sites: (1) at Yudomari

349 Forest (where now destroyed) and (2) western branch of Futamata River; 180-390 m altitude.

350 Humid evergreen forests near streams dominated by trees of Machilus thunbergi Siebold \&

351 Zucc., Distylium racemosum Siebold \& Zucc., Eurya japonica Thunb., and Ardisia sieboldii

352 Miq. The topography is flat, with c. $50 \%$ of the ground surface covered with three species of

353 ferns: Arachnoides amabilis (Blume) Tindale, Ctenitis subglandulosa (Hance) Ching and

354 Diplazium domianum (Mett.) Tardieu. Shrubs are Damnacanthus indicus Gaertn.f. and Maesa

355 japonica (Thunb.) Moritzi ex Zoll. (Yahara \& Tsukaya 2008).

356 Etymology: commemorating Hiroaki Yamashita, photographer, of Yaku Island, who first

357 noticed this species in Oct. 2000 and brought it to the attention of the botanist Yahara in Oct.

358 2006, after photographing it (Yahara \& Tsukaya 2008).

359 Local name: Yaku-no-hina-hoshi (Yahara \& Tsukaya, 2008).

360 Additional specimens: none are known.

361 Conservation: Oxygyne yamashitae is not listed on iucn.redlist.org (accessed 30 April 2017),

362 however, it is listed as Critically Endangered CR D on the Global Red List of Japanese

363 Threatened Plants (www.kahaku.go.jp accessed 30 April 2017) which cites Kato \& Ebihara

364 (2011).

365

366 Yahara and Tsukaya (2008) stated that of the two known populations of O. yamashitae, which

367 was first discovered at Yudomari, one was destroyed by construction of a forest road. They

368 expect that additional populations might yet be found in other forest in the area. However, so far

369 none have been found (K. Suetsugu pers. comm., 2017). The second population at the Futamata

370 River is in an area designated as National Forest, within which are allowed forest logging and

371 construction, such as road construction, which destroyed the first population. Clearly, the only

372 known surviving population is under threat. Yahara \& Tsukaya (2008) provided detailed

373 populational data. Yamashita noticed a plant of the first population in early October 2000, and at

374 the second location in early October 2006, showing a photograph of it to Yahara soon after. A

375 search by Yamashita and Yahara on $4^{\text {th }}$ October 2007 failed to find any plants, but another search

376 on $24^{\text {th }}$ October 2007, by Yamashita and Fuse, recorded 11 flowering individuals, two of which

377 were collected for study and preservation. Fuse, Yahara and Tsukaya revisited this site on 28

378 October 2007 and found more than 30 flowering individuals, four of which were collected. 
Oxygyne yamashitae is perhaps the most distinct and morphologically isolated of all of

380

381

382

383

384

385

386

387

388

389

390

391

392

393

394

395

396

397

398

399

400

401

402

403

404

405

406

407

408

409

the six known species of the genus: (1) While other species have the anthers inserted into the central aperture above the stigmas, or in slits between the lamellae (O.duncanii, O. shinzatoi) the anthers of $O$. yamashitae are unique in each being inserted into three separate apertures developed within the lamellae. (2) While in all the other species the stigmas are well included within the perianth, in O. yamashitae they are halfway along the tube. (3) The three lateral style appendages are entire in all species except $O$. yamashitae, where they are bifurcate. (4) The staminal filament in all species is more or less cylindrical (except $O$. duncanii and at the base in $O$. frankei) and lacks appendages, except in O. yamashitae where it is highly dorsiventrally flattened and bears two lateral pairs of long teeth, each far broader than the filament (Fig. 4); this latter character is also seen in Tiputinia and may be homologous.

\section{Oxygyne shinzatoi (H.Ohashi) Tsukaya (Tsukaya, 2016: 195)}

Holotype: Japan, Ryukus Islands, Okinawa Prefecture, Okinawa Island, Yona, fl. 18 Sept 1974, T. Shinzato s.n. (RYU n.v. herbarium specimen). (Figs. 1 and 5)

Saionia shinzatoi H.Ohashi (Ohashi 2015:116). Homotypic Synonym.

Saionia shinzatoi Hatus. (Hatusima 1975: 909; Hatusima \& Nackejima 1979: 342, fig. 583;

Hatusima \& Amano 1994: 326; Anon. 1996: 111) nom. inval.

Oxygyne shinzatoi (Hatus. ex H.Ohashi) C. Abe \& Akasawa (Abe \& Akasawa 1989:163) nom. illeg.

Perennial herbs, achlorophyllous, mycoheterotrophic. Roots creeping, c. 2-3 cm long. Stem simple or branched, erect, glabrous, $1-2.5 \mathrm{~cm}$ tall. Inflorescence racemose, (1 or) 2-5-flowered, bearing scale-like bracts, white, shortly pedunculate; peduncle c. $1.2 \mathrm{~mm}$ in diameter. Bracts at base of flowers, (3-)5 or more, to $5 \mathrm{~mm}$ long, ovate-lanceolate to lanceolate, white. Flowers c. 5 $\mathrm{mm}$ long, 9-12 $\mathrm{mm}$ in diameter, bluish verdigris. Perianth tube campanulate, c. $5 \mathrm{~mm}$ long, 3 $\mathrm{mm}$ in diameter, 6-lobed, glabrous, lobes pale blue (young stage) or white (older stage), narrowly triangular, elongate, c. 3-5 mm long, $0.6 \mathrm{~mm}$ wide at base. Each perianth lobe with callus-like cluster of round cells on adaxial surface at base; callus cluster $0.5 \mathrm{~mm}$ long; with 3 trapezoid lamellae from inner perianth lobes, trapezoid lamellae c. $0.7 \mathrm{~mm}$ wide, with 3 or 4 shallow apical 
410 teeth, bluish verdigris, curved downward from throat of perianth tube, forming 3 narrow slits and 411 a small opening at centre of throat. Perianth lobes and lamella bluish verdigris. Stamens 3, 412 elongating from base of outer perianth lobes, filaments curved downward between trapezoid 413 lobes on throat of perianth tube; anthers apical, pale yellow, bithecal, $0.7 \mathrm{~mm}$ long. Ovary c. 3 $414 \mathrm{~mm}$ long, white. Style 1, $1 \mathrm{~mm}$ long, thick, bilateral, surrounded by 2 or 3 appendages, with 2 or 4153 short unequally sized sickle shaped stigmas; stigmas less than c. $0.4 \mathrm{~mm}$ long, $0.2 \mathrm{~mm}$ wide.

416 Tip of style appendages ball-like, rounded, c. $0.3 \mathrm{~mm}$ in diameter, c. $0.5 \mathrm{~mm}$ long including 417 stalk. Ovules many, $0.3 \mathrm{~mm}$ long. Fruit fusiform, bluish, verdigris; seeds numerous (from 418 Tsukaya 2016).

419 Phenology: Flowering in September and October.

420 Distribution \& habitat: only known from the type location, in forest of Pinus luchuensis Mayr 421 and Schima wallichii (DC) Korth. subsp. liukiuensis (Nakai) Bloemb. (Hatusima 1975), and 422 Schima superba Gardner \& Champ. (Anon. 1996) and Machilus thunbergiii Siebold \& Zucc., 423 Camellia japonica L., C. sasanqua Thunb., Dendropanax trifidus (Thunb.) Makino ex Hara, and 424 Schefflera heptaphylla (L.)Frodin (Tsukaya 2016)

425 Etymology: commemorating the collector of the first specimens, T. Shinzato.

426 Local name: Hoshizaki-shakujuyô (Hatusima, 1975); Hoshizaki shakujou (Anon. 2000);

427 Nansei-shoto (Ministry of the Environment, Japan 2016).

428 Additional specimens: all from same location as the type: 20 Sept. 1972 T. Shinzato s.n. (RYU 429 n.v.); ibid. (now an experimental field site of Ryukyu University) 8 Oct. 2006, H. Tsukaya 430 s.n.(TI!, TNS!); ) 8 Oct. 2006, M. Yokota s.n. (RYU n.v.).

431 Conservation:_Oxygyne shinzatoi is listed as Critically Endangered CR (D) on both 432 iucn.redlist.org (accessed 30 April 2017: see below), and on the Global Red List of Japanese 433 Threatened Plants (www.kahaku.go.jp accessed 30 April 2017) which cites Kato \& Ebihara 434 (2011).

436 We concur with the assessment of Critically Endangered assigned this species by Anon. (1996) 437 and Kato \& Ebihara (2011), even though we have not seen supporting evidence of either threats 438 to $O$. shinzatoi or number of mature individuals being $<50$, or any of the other data needed to 439 evidence this category under another criterion using the IUCN (2012) standard. This is because 440 the species is known from a single location and is rarely seen. It has been reported only in the 
441

442

443

444

445

446

447

448

449

450

451

452

453

454

455

456

457

458

459

460

461

462

463

464

465

466

467

468

469

470

471

years 1972, 1974, 2004, 2008 and 2011. In 1996 it was reported that it had not been seen for 20 years (Anon. 1996). However, it is not clear whether the plants had been regularly searched for each year at the correct season. The type location is private land and so is not open to visitors $(K$. Suetsugu, pers. comm. 2017).

The Ministry of the Environment, Japan (2016) are credited with the entry for this species on www.iucnredlist.org, which also maintains the species as Critically Endangered (CR D) since "only several individuals were found during a search in 2011". Its habitat is stated to be inside a University Forest (specifically attached to the Faculty of Agriculture, University of the Ryukyus at Yona, Kunigusuju-son, fide Anon. 1996) and well protected, though small-scale logging is ongoing. In order to strengthen the protection of the subtropical evergreen broadleaved forest, including the habitat of this species, a new National Park was designated (The Ministry of the Environment, Japan 2016). Yambaru National Park, located in the northern part of Okinawa Island was designated as the 33rd National Park in Japan on September 15, 2016 https://www.env.go.jp/en/nature/nps/park/yambaru/point/index.html.

Oxygyne shinzatoi is perhaps the most well-studied of all species of Oxygyne; it is the only species for which cytological (Tsukaya et al., 2007) and molecular phylogenetic studies (Yokoyama et al., 2008) exist. It remained nomenclaturally invalidly published for many years since its first discovery in 1972, since two holotypes (contrary to the Code) were proposed by its discoverer Hatusima in the original publications where it was named Saionia shinzatoi (Hatusima, 1975, 1976). Abe \& Akasawa (1989:163), evidently unaware of the invalidity, had transferred the species to Oxygyne where it continued to be invalid. Ohashi (2015) rectified the matter of validity by selecting a single holotype, indicating that he expected the correct name to be then Oxygyne shinzatoi (Hatus. ex Ohashi) C. Abe \& Akasawa. However, since there is no retroactivity in this matter according to the Code, it was not until Tsukaya (2016) made the combination that the name was validly transferred to Oxygyne.

3. Oxygyne hyodoi C. Abe \& Akasawa (Abe \& Akasawa 1989:161 fig.1; Tsukaya 2016: 196)

Holotype: Japan, Shikoku, Ehime Prefecture, Minamiuwa-gun, Nishiumi-Cho, in evergreen forest, fl. 9 Oct 1988, Syozi Hyodo s.n. (TI! Herbarium specimen). (Figs. 1 and 6). 
472 Saionia hyodoi (C. Abe \& Akasawa) H. Ohashi (Ohashi 2015:117). Homotypic Synonym.

473

474 Perennial herbs, achlorophyllous, mycoheterotrophic. Roots creeping, c. 1-2 cm long,

475 internodes fusiform, creamy white. Stem simple, erect, glabrous, 2-3 cm tall. Inflorescence

476 racemose, shortly pedunculate, 1-3-flowered. Leaves scale-like membranaceous, c. 1.2-1.6 mm

477 long, emerald green when fresh. Bracts at base of flowers c. $3 \mathrm{~mm}$ long. Flowers c. $4 \mathrm{~mm}$ long,

$4782 \mathrm{~mm}$ wide, emerald green. Perianth urceolate-campanulate, tube c. $3 \mathrm{~mm}$ long, 6-lobed,

479 glabrous, lobes c. $2 \mathrm{~mm}$ long, 3-4 mm wide, triangular-semiorbiculate, apices filiform. Annulus

480 forming a convex dome over the mouth of the perianth tube, with a central aperture into which

481 the stamens descend. Stamens 3, from junction between annular taenia and perianth lobes,

482 filaments curved downward. Style 1, thick, bilateral, c. $1.4 \mathrm{~mm}$ long, with 3 clavate lateral

483 appendages on upper surface, stigmas 3, short (modified from Tsukaya 2016).

484 Phenology: Flowering in October

485 Distribution \& habitat: known only from the understorey of evergreen forest at the type

486 location, where it was recorded growing with Burmannia liukiuensis Hayata (Abe \& Akasawa 487 1989).

488 Etymology: commemorating Syozi Hyodo, member of the Nippon Fernist Club, collector of the 489 type specimen and discoverer of the first known specimen of Oxygyne hyodoi (Abe \& Akasawa 490 1989).

491 Local name: Hina-no-bonbori (Abe \& Akasawa 1989; Anon. 2000)

492 Additional specimens: nil

493 Conservation: Oxygyne hyodoi is not listed on iucn.redlist.org (accessed 30 April 2017),

494 however, it is listed as Critically Endangered (CR D) on the Global Red List of Japanese

495 Threatened Plants (www.kahaku.go.jp accessed 30 April 2017) which cites Kato \& Ebihara 496 (2011).

497 However, we assess the species as extinct since "Oxygyne hyodoi has not been found 498 again" (Ohashi, 2015: 115) despite repeated targeted searches for it at the type locality by 499 botanists (e.g. "We could not find this species during our research in 2001" Anon. 2003)

500 including those experienced in observing Japanese Oxygyne species (Suetsugu pers. obs., 2017).

501 Among these is the original discoverer of the species, Mr Hyodo, an enthusiastic field botanist

502 who was reported to have returned to the original site every year for 15 years but has not 
503 succeeded in finding his species (Stephan Gale, pers. comm. to Cheek 7 Dec. 2007). An

504 immature specimen once tentatively considered to be this species, discovered near Kobe City,

505 Hyogo Prefecture (Kobayashi \& Kobayashi, 1993), is now considered most likely a Thismia. In

506 any case, natural habitat at that site has been lost to a development project for an industrial park

507 (Anon. 2001).

508 Drawings in the protologue of the flower in three dimensions clearly show that the

509 stamens are inserted into the central aperture of the annulus dome, and that in fruit only the basal

510 rim of the perianth tube walls, and its base, together with the style, remain.

511 The local name signifies "lantern of a lady doll", probably in reference to the shape of the

512 perianth, according to Shigeo Yasuda (pers. comm. 14 Dec. 2005).

513

4. Oxygyne duncanii Cheek sp. nov.

515 Holotype: Cameroon, SW Region, saddle between Mt Cameroon and Mt Etinde, 1300 m alt., fl.

516 fr. 25 Oct. 1992, Cheek 3816 (holotypus SCA herbarium specimen!; isotypus K spirit specimen!)

517 (Figs. 1, 7 and 8)

518

519 Oxygyne sp. nov. Cheek \& Ndam (1996: 613, 614); Cheek \& Williams (2000: 41); Cheek in

520 Cable \& Cheek (1998: 1xv, 149).

521

522 Affinities (Diagnosis): differs from all other species of Oxygyne Schltr. in the presence of a pair

523 of globose structures below the staminal filament insertion; the erect apiculus from the midpoint

524 of the adaxial surface of the perianth lobes; and the stigma for which the central, distal stigmatic

525 portion is 3-angled, not 3-lobed.

526

527 Achlorophyllous mycoheterotroph, glabrous, a single flower above the surface, the whole plant

528 25-30 mm high from tip of root to top of flower. Roots white 5-6, vermiform, radiating from the

529 base of the rhizome, rarely branched and then articulated at the junctions, c. $1 \mathrm{~mm}$ diameter,

530 lacking root hairs, surface papillate. Stems rhizomatous, 1-3 per plant, white, \pm erect,

531 unbranched, terete, 1-1.5 mm diam; scale-leaves inserted spirally, 2-3 on the upper half of the

532 rhizome, translucent, oblong or lanceolate, c. $2 \times 0.6 \mathrm{~mm}$, obtuse. Inflorescence 1-flowered,

533 bracts 3, in one whorl, equal, erect, subtending the flower, hyaline, oblong-triangular, 2.5-3 $\times$ 
534 c. $1.5 \mathrm{~mm}$, slightly convex, becoming accrescent and valvate around the fruit. Flowers erect,

535 c. $7 \mathrm{~mm}$ long, $9-10 \mathrm{~mm}$ wide, perianth tube brownish orange, black in $0.5 \mathrm{~mm}$ near ovary,

536 glossy, campanulate, c. $3.5 \mathrm{~mm}$ long, c. $2 \mathrm{~mm}$ wide at the base, c. $4 \mathrm{~mm}$ wide at the apex,

537 sometimes slightly constricted at the midpoint, even, lacking ridges; perianth lobes patent to

538 slightly ascending, triangular, c. $3 \times 1.5 \mathrm{~mm}$, adaxial surface with margin raised in the proximal

539 part, or the margins uniting $2 \mathrm{~mm}$ from the base, before an erect mucro $0.2-0.3 \mathrm{~mm}$ high, distal

540 part of lobe extending a further $1 \mathrm{~mm}$, subfiliform. Androecium with three fertile stamens

541 inserted at junction of perianth lobes and tube, the filaments with an adaxial pair of globes at the

542 base, each c. $0.6 \mathrm{~mm}$ diameter, inserted on the rim of the perianth tube, the filaments themselves

543 dorsiventrally flattened, c. $3.3 \mathrm{~mm}$ long, c. $0.35 \mathrm{~mm}$ wide at base, c. $0.25 \mathrm{~mm}$ wide at apex, erect

544 at base, then strongly incurved, anthers extrorse, thecae \pm elliptic, collateral, c. $0.5 \times 0.2 \mathrm{~mm}$,

545 inserted on the lower surface of a circular-elliptic connective c. $0.9 \times 0.6 \mathrm{~mm}$. Annulus inserted

546 immediately below the stamens inside the mouth of the perianth tube, brownish-orange,

547 incomplete, of 3 lamellae, each opposite the three sterile (inner) perianth lobes, in spirit material

548 involute from apex and $1.5 \mathrm{~mm}$ wide; when unfurled with a proximal transversely rectangular

549 portion, then transversely cylindrical, c. $0.5 \mathrm{~mm}$ diameter, c. $1 \mathrm{~mm}$ long, and a distal bifurcate

550 portion c. $1 \mathrm{~mm}$ long, $0.5 \mathrm{~mm}$ wide, the apical sinus c. $0.5 \mathrm{~mm}$ deep, the two lobes filiform; in

551 vivo the lamellae extend horizontally, seamlessly occluding the mouth of the perianth tube

552 except for a depressed central circular pore c. $1 \mathrm{~mm}$ diameter and 3 anther slits between the

553 lamellae.

554 Ovary white, campanulate, c. $1.5 \mathrm{~mm}$ long, c. $0.7 \mathrm{~mm}$ wide at base, $2 \mathrm{~mm}$ wide at apex,

555 unilocular, placentae 3, attached distally near the junction with the perianth floor. Style-stigma

556 1.1-1.4 mm long, style terete, c. $0.5 \times 0.2 \mathrm{~mm}$ style-head/stigma with a 3 -angled head c. $0.5 \times$

$5570.5 \mathrm{~mm}$ and with 3 lateral lobes, the lobes erect, $0.3-0.5 \mathrm{~mm}$ long, acute. Fruit (probably

558 immature) translucent-white, narrowly cylindrical-campanulate, $3.5 \times 2.5 \mathrm{~mm}$, apex truncate

559 and, pre-dehiscence, a central umbo (style remnant), the central part aperturate by deliquescence,

560 with a ragged margin (perianth tube remnants); bracts almost enveloping the fruit, valvate, c. 3.2

$561 \times 2 \mathrm{~mm}$ long

562 Phenology: Flowering in October.

563 Distribution \& habitat: North facing slope, c.10-20 m from bottom of a shady valley drained

564 by a small (seasonal?) stream. Submontane evergreen forest dominated by Garcinia $\mathrm{cf}$. 
565 smeathmannii (Planch. \& Triana) N.Robson ex Spirel., with some Pseudagrostistachys africana

566 Pax \& K.Hoffm., Psychotria camptopus Verdc. and Cola cf. verticillata Stapf ex A.Chev., herbs

567 including Plectranthus, Palisota mannii C.B.Clarke, Dracaena spp., Oplismenus hirtellus

568 (L.)P.Beauv.and Selaginella spp., Impatiens etindensis Cheek \& Eb. Fisch. and I. frithii Cheek,

569 Renealmia sp., Pteris spp.; 1300-1400 m alt.

570 Etymology: The epithet commemorates Duncan Thomas, the most prolific living collector of

571 plant specimens in Cameroon, with whom the species was collected. He has striven to build the

572 capacity of its botanists. It was Dr Thomas who supervised the forest plot enumeration during

573 which the type specimen of $O$. duncanii came to light.

574 Conservation: This species is known from only four plants (three in flower, one in fruit) in one

575 area of about 2 square metres, despite about four hours subsequent continuous searching by each

576 of four botanists in the valley in which the discovery was made, and in the adjacent valley. No

577 obvious threats were detected at the time of discovery, apart from a seasonally occupied hunters'

578 camp nearby. Accordingly, using the criteria of IUCN (2012), Oxygyne duncanii is here

579 formally assessed as CR D1, that is, Critically Endangered, since less than 50 mature individuals

580 are known. The species was first assessed thus by Cheek (in Cable \& Cheek, 1998: 1xv), as

581 Oxygyne sp. nov. However, since the species had not been formally published, it was not then

582 possible for this assessment to be accepted by IUCN.

583 While it is not impossible that more localities exist for $O$. duncanii, it is worth noting that

584 Mt Cameroon and Mt Etinde are relatively well-surveyed botanically by West African standards.

585 During the period 1992-1994, a series of surveys at these locations produced 9,600 specimens,

586 the basis for a checklist (Cheek in Cable \& Cheek, 1998: xxi). Prior to this, at least 28 botanists

587 had visited Mt Cameroon and collected specimens, beginning with Gustav Mann in 1861 (Cable

$588 \&$ Cheek, 1998). While achlorophyllous mycoheterotrophs such as Oxygyne can easily be

589 overlooked by the general collector, several mycoheterotroph specialists have worked on and

590 around Mt Cameroon. These are documented in some detail under Oxygyne triandra (above).

591 Most notably, Cameroon's most prolific discoverer of achlorophyllous mycoheterotrophs, Moses

592 Sainge, is often based on Mt Cameroon a few km away at the University of Buea.

593 In contrast with $O$. triandra, which was recorded in a community with five other

594 mycoheterotrophs (see under that species), no additional mycoheterotrophs were found in

595 association with $O$. duncanii, despite searching over several hours by several botanists. 
596 Generally in Cameroon, mycoheterotrophs occur at relatively low altitudes, below $800 \mathrm{~m}$, and it 597 is unusual to find a species at such high altitude as this, at $1300-1400 \mathrm{~m}$, in submontane forest.

598 We conjecture that this submontane species evolved from a common ancestor with the lowland 599 O. triandra, although morphologically it appears more similar to the Japanese species.

600 The horizontal separation of the type (and only) localities of Oxygyne triandra and $O$. 601 duncanii, is about $12 \mathrm{~km}$, the vertical separation about $1 \mathrm{~km}$.

602 Mt Etinde, the subpeak of Mt Cameroon, has a different age and geology, and 603 consequently, a different flora to that of Mt Cameroon, the main massif. Unlike Mt Cameroon, it 604 is not volcanically active, but the result of geological uplift of plutonic rocks, and predates the 605 larger mountain (Cable \& Cheek, 1998). As a result, this region includes many rare species that 606 are not found on the main massif, including several that are endemic to Etinde, such as Coffea 607 leonimontana Stoff. (Stoffelen et al., 1997) and Impatiens etindensis Cheek \& Eb. Fisch. (Cheek $608 \&$ Fischer 1999). It also contains species that are otherwise found only in the Bakossi Mts, c.60 $609 \mathrm{~km}$ to the north of Mt Cameroon, including Dracaena kupensis Mwachala, Cheek, Eb.Fisch. \& 610 Muasya (Mwachala et al., 2007), Deinbollia oreophila Cheek (Cheek \& Etuge, 2009) and 611 Impatiens frithii Cheek (Cheek \& Csiba, 2002).

612 No scent was detected from the flowers, nor pollinators observed during the hours of the 613 afternoon when this plant was discovered and surveyed, and last seen (Cheek personal 614 observations, 2017).

615 In life the lamellae form a dome over the mouth of the perianth, with a central aperture 616 and three inconspicuous radial anther slits (Fig 7). It is possible that the filiform extensions of the 617 lamellae with their capitate apices serve to join firmly the edges of the lamellae into a single 618 structure by locking with each other. In the high rainfall habitat in which this and most other 619 species of the genus occur, the dome could serve to prevent raindrops from flooding the perianth 620 tube, which would obstruct pollination and reproduction.

621

622

623

5. Oxygyne triandra Schltr. (Schlechter 1906:140; Jonker 1938: 47, 260-261; Hepper 1968: 179)

624 Holotype: Cameroon, "Urwald bei Moliwe", Sept. 1905, Schlechter 15790 (holotype B,

625 herbarium specimen). (Figure 9)

626 
627 Achlorophyllous mycoheterotroph, glabrous, $3.8 \mathrm{~cm}$ high. Underground parts unknown.

628 Stems erect, unbranched, terete, 1-2 mm diameter; scale-leaves c. 10 per stem, inserted spirally, 629 oblong-ovate, $1.25 \times 1 \mathrm{~mm}$, apex lacerate. Inflorescence 1-flowered, bracts 3, apparently in one 630 whorl, equal, erect, subtending the flower, ovate, $8 \mathrm{~mm}$ long. Flower erect, c. $22 \mathrm{~mm}$ long, 631 perianth tube dark brown, campanulate-cylindrical, c. $10 \mathrm{~mm}$ long, c. $7 \mathrm{~mm}$ wide at the throat, 632 longitudinally 6-pleated; perianth lobes orange-yellow, erect (possibly an artefact of 633 preservation), $12 \mathrm{~mm}$ long, $1.55 \mathrm{~mm}$ wide, basal part oblong, apex narrowly caudate-elongate, 634 highly acute. Androecium with stamens inserted at junction of corolla throat and base of outer 635 perianth lobes, filaments terete, $0.1 \mathrm{~mm}$ wide, basally erect, above arched downwards; anthers 636 elliptic, $1 \times 0.75 \mathrm{~mm}$, deflexed, apex rounded, lacking appendages; annulus of three lamellae, 637 each opposite the inner perianth lobes, transversely oblong-ovate, c. $1 \times 0.75 \mathrm{~mm}$, apex bifid, 638 lobes $0.25 \mathrm{~mm}$ long, acuminate, each sometimes shortly bifid. Style thick, 3-ribbed, stigma 639 trifid, the branches erect, subulate. Ovary with three parietal placentae, each three times as long 640 as the stalk (Jonker 1938: 261). Fruits obovoid-truncate, c.4 mm long, apex of the persistent 641 basal ring of the perianth and with the persistent style (Jonker 1938: 261).

642 Phenology: Flowering in September.

643 Distribution \& habitat: known only from the type specimen, which indicated "urwald bei 644 Moliwe" (forest by Moliwe). Moliwe is in the geologically ancient eastern foothills (rising to $645200-300 \mathrm{~m}$ asl.) of Mt Cameroon, in an area that was lowland evergreen rainforest, with annual 646 rainfall of 3-4 m per annum (Cheek 1992, Cable \& Cheek 1998). The ecology of the remnant of 647 forest that remains, formerly known as Mabeta-Moliwe, now better known as Bimbia648 Bonadikombe, was documented in detail in Cheek (1992). A summary can be found in Cable \& 649 Cheek (1998). Apart from Oxygyne triandra, numerous other narrowly endemic and threatened 650 species are recorded from this forest, e.g. Drypetes moliwensis (Cheek et al., 2000), Cola 651 cecidifolia Cheek (Cheek, 2002), Salacia nigra Cheek (Gosline et al., 2014), Psychotria

652 moliwenis Bridson \& Cheek, P. bimbiensis Bridson \& Cheek (Cheek \& Bridson, 2002) and 653 Ancistrocladus grandiflorus Cheek (Cheek, 2000).

654 Etymology: "triandra" signifies the three stamens, unique to this genus among thismiaceous 655 genera.

656 Local name: none recorded.

657 Additional specimens: none are known. 
658 Conservation: Oxygyne triandra was listed as Critically Endangered (CR A1c+2c) by Cheek 659 (Cable \& Cheek, 1998: 1xv). This assessment was later published on the IUCN redlist website 660 iucn.redlist.org where it is attributed to Cheek \& Cable (2000). The assessment of Oxygyne 661 triandra was updated to CR B2ab(iii)+D by Cheek in Onana \& Cheek (2011:358) where it was 662 stated "the prospects of refinding this must be very low ....". Oxygyne triandra was given as an 663 example of a species now thought to be globally extinct (Cheek \& Onana, 2011:7). It has never 664 been seen since it was first discovered in 1905, despite numerous targeted searches by multiple 665 groups of expert achlorophyllous plant researchers at the correct season over many years (see 666 below).

667

Although most of B was destroyed by allied bombing in 1943, many of the monocot specimens 669 survived, including the type of Oxygyne triandra (

670 http://ww2.bgbm.org/Herbarium/specimen.cfm? Barcode=B100277415 )

671

672

Attempts to rediscover Oxygyne triandra

673 The Oxford University expedition to Mt Cameroon (July-Sept 1993) had the rediscovery of this 674 species, together with Afrothismia pachyantha Schltr. and A. winkleri (Engl.) Schltr. as a key 675 objective, but failed to find them in the Moliwe area or elsewhere in the lowlands of Mt 676 Cameroon (Baker et al., 1995). Targeted searches by the first author with teams of other 677 botanists during 1992-2007 also failed to find Oxygyne triandra, initially at Moliwe and 678 Mabeta-Moliwe, later in numerous other evergreen forest areas in SW Region Cameroon as part 679 of comprehensive species surveys to support conservation management. These surveys are 680 documented by Cheek et al. (2004, 2010) and Harvey et al. (2004, 2010). Despite this, the 681 surveys did discover several other achlorophyllous mycohetrotrophic species (Cheek \& Ndam, 682 1996), including some new to science e.g. Kupea martinetugei Cheek \& S. Williams (Cheek et 683 al., 2003; Cheek, 2004a) and Afrothismia amietii Cheek (Cheek 2007). Further targeted searches 684 for Oxygyne triandra by other research groups also failed to find the species, notably those over 685 several years led by mycoheterotroph specialists Thassilo Franke (late 1990s to early 2000s) then

686 by Vincent Merckx and Moses Sainge (Sainge et al. 2010). These expeditions also discovered 687 new species of the closely related Afrothismia (Franke, 2004, Franke et al., 2004; Merckx, 688 2008). While new discoveries of mycoheterotrophs throughout Africa have extended the 
689 geographic range of the genus and since 2000 more than tripled the number of species of 690 Afrothismia (e.g. to Kenya: Afrothismia baerae Cheek (Cheek 2004b), to Tanzania: Afrothismia 691 mhoroana Cheek (Cheek \& Jannerup 2006), and Malawi A. zambesiaca Cheek (Cheek 2009), 692 no further records of Oxygyne have been made, apart from O. duncanii and O. frankei (this 693 paper).

694 Analysis of Schlechter's specimens (Cheek \& Ndam 1996) reveals that he collected 695 several other species of mycoheterotroph in a series consecutive with Oxygyne triandra 696 (Schlechter 15790). This supports Schlechter's observation that his Oxygyne triandra occurred in 697 a community with other Burmanniaceae sensu lato, and with Sebaea, just as Ridley had reported 698 in the Malay Peninsula (Schlechter, 1906). Clustering together of mycoheterotrophs in one place 699 is known in Africa and South America (Schlechter, 1906, Cheek \& Ndam, 1996, Cheek \& 700 Williams, 2000). The consecutive Schlechter collections are:

701

702 Burmannia hexaptera Schltr.

703 Burmannia congesta (Wright) Jonker

704 Afrothismia winkleri (Engl.) Schltr.

705 Afrothismia pachyantha Schltr.

706 Sebaea oligantha Schinz

707

708

709

710

711

712

713

714

715

716

717
Schlechter 15785 \& 15786

Schlechter 15787

Schlechter 15788

Schlechter 15789

Schlechter (in obs.)

Examination of the type specimen in 2006 showed that the illustrations in the protologue (Schlechter, 1906) were misdrawn, in so far as (1) the stem is largely sheathed in scales, and (2) the annulus is not continuous, instead lamellae are present only opposite the inner (sterile) perianth lobes and are absent from the outer perianth lobes. The description above is based on that of the protologue modified by observations made of the type in 2006 by the first author. There are several discrepancies between the description in the protologue and that of Jonker (1938). While Schlechter states that the plants were 1-flowered, and that fruit were absent, Jonker (1938) states that they are 3-flowered and describes the fruit. 
718 Holotype: Central African Republic, 40km N Bambari, près Balimbwa, fl. fr. 25 July 1928,

719 Tisserant 2623 (holotype BM000803697; isotypes P00319728, P00319729 images, all

720 herbarium specimens) (Figs 1 and 10)

721

722 Affinities (Diagnosis): differs from Oxygyne triandra Schltr. in the lamellae oblong, lacking

723 lobes, in the perianth lobes white, 5-5.5 mm long, (not brown, $10 \mathrm{~mm}$ long).

724

725 Achlorophyllous mycoheterotroph, glabrous, a single flower above the surface, the perianth tube

$7262-3 \mathrm{~mm}$ diameter. Roots not seen. Stems rhizomatous, white, \pm erect, unbranched, terete, $0.5-$

$7270.75 \mathrm{~mm}$ diam; scale-leaves not seen. Inflorescence 1-(2-)flowered, bracts several, erect, 728 subtending the flower, hyaline, oblong, c. $0.8 \times 0.2 \mathrm{~mm}$, apex obtuse or acuminate, slightly 729 convex, becoming persistent around the fruit. Flowers erect, dark green, base of the perianth 730 orange-brown, tube campanulate, $3.5-5 \mathrm{~mm}$ long, (2-)3 $\mathrm{mm}$ wide, widening gradually from base 731 to apex, sometimes slightly constricted at midpoint, lacking ridges, sometimes with 6

732 longitudinal dark lines corresponding with the perianth lobes. Perianth lobes white, erect, 5-5.5

$733 \mathrm{~mm}$ long, proximal part oblong or triangular, 0.8-1.2 mm long, 0.6-1 mm wide, apex narrowing

734 abruptly to the long, linear distal part, 0.1-0.2 mm wide, margins involute, apex obtuse. Stamens

735 3, opposite outer perianth lobes, inserted at junction of perianth lobe and tube, the filament c. 1.5

$736 \mathrm{~mm}$ long, flattened, proximal $2 / 5$ triangular, base erect, about as wide as perianth lobe base,

737 narrowing to the strongly incurved, filamentous, $0.1(-0.2) \mathrm{mm}$ wide distal part; anthers borne at

738 same level as filament base, extrorse, thecae collateral, inserted on the lower surface of

739 connective, elliptic c. $0.3 \times 0.2 \mathrm{~mm}$. Annulus of 3 lamellae, inconspicuous, lamellae inserted at

740 the same level as the stamens at the base of the inner (sterile) perianth lobes, each lamellum

741 transversely oblong to quadrate, $0.2 \times 0.2 \mathrm{~mm}$, appressed to perianth tube (possible artefact of

742 preservation). Ovary ellipsoid-campanulate, c. $1.5 \mathrm{~mm}$ long, c. $1 \mathrm{~mm}$ wide, unilocular, placentae

743 3, attached distally near the junction with the perianth floor. Style-stigma $2 \mathrm{~mm}$ long, style terete,

$7441 \mathrm{~mm}$ long, style with three erect, subulate-filiform lobes $1 \mathrm{~mm}$ long, apices acute. Fruit

745 ellipsoid, $3 \times 2 \mathrm{~mm}$, bracts enveloping the fruit, $3.5-4 \times 1.52 \mathrm{~mm}$ long. Seeds ovoid, bright

746 yellow-orange, $0.3-0.4 \mathrm{~mm}$ long, epidermal cells convex.

747 Phenology: Flowering and fruiting in late July. 
748 Distribution \& habitat: Habitat not well recorded, presumed to be gallery forest "Under the 749 roots of Gramineae, places more or less damp" ("sous racines du graminées, endroit humides");

750 c.450 m asl (read from Google Earth).

751 Etymology: Named for Thassilo Franke, formerly active in research on C. African

752 achlorophyllous mycoheterotrophs, who first discovered this species to be a new Oxygyne.

753 Local name: none recorded.

754 Additional specimens: none are known.

755 Conservation: Oxygyne frankei is here assessed as Critically Endangered (CR D) since less than

756

757

758

759

760

761

762

763

764

765

766

767

768

769

770

771

772

773

774

775

776

777

778

50 mature individuals are recorded. No immediate threats are visible on Google Earth. No road access and no settlements appear in the area. However, iron ore mining is reported as a possibility in the area. Extensive botanical surveys were carried out in C.A.R. since the 1980s by Mike Fay and David Harris, but no additional collections of Thismiaceae have been made ( $D$. Harris pers. comm., Dec. 2017). However, no targeted searches have been made for this species, and since habitat in the type location appears to be intact, there is every possibility that the species survives there. Botanical surveys are not currently advisable in C.A.R. due to the security risk (https://www.gov.uk/foreign-travel-advice/central-african-republic visited 10 Dec. 2017).

Notes: The holotype was formerly in the private collection of Georges le Testu (18771967) who bequeathed it to BM in 1967. The main label appears in the hand of the collector, the Reverend Charles Tisserant. His identification is "Cytinacée, Hydnora". The first annotation is a label signed "L.D. Gómez-P." dated Sept. 1983, with the inscription “Thismia intermedia sp. nov. Holotypus." This name was not published and the writer has not been traced. The specimen was then annotated as Oxygyne sp. by T. Franke in 2002, and then as Oxygyne sp. nov. by T. Franke in 2008. However, T. Franke is reported to have left botany since that time.

The discovery of $O$. frankei in C.A.R. was unexpected for several reasons. In contrast with the locations of all other species of the genus, the Bambari area (in fact the C.A.R. as a whole), is not renowned for its high species diversity or for the presence of narrowly endemic species. Unlike all other species of the genus, this species occurs far from the sea $(1280 \mathrm{~km}$ as measured with Google Earth), in an area where evergreen forest does not predominate, and where rainfall is $<2 \mathrm{~m}$ p.a. Rainfall at Bambari is reported as $1.47 \mathrm{~m}$ p.a., mainly falling (months with $>100 \mathrm{~mm}$ ) from April-October (https://en.wikipedia.org/wiki/Bambari downloaded 10 Dec. 2017). The predominant vegetation type is woodland. However, at the type locality $40 \mathrm{~km} \mathrm{~N}$ of 
779 Bambari appears a dense network of evergreen gallery forest on a low, flat plateau. These forest

780 regions seem to depend on shallow, branching drainage lines. Although rainfall is below the $2 \mathrm{~m}$

781 threshold usually needed to support evergreen forest, the gallery forest is likely to be sustained

782 by water draining from the slightly higher woodland areas.

783 That such a relictual, point-endemic species as Oxygyne frankei should occur in gallery

784 forest in a predominantly woodland area indicates that other such point-endemics might be found 785 if survey effort was focused in such habitats.

786 The morphological affinities of $O$. frankei are clearly with $O$. triandra of Cameroon. The

787 preserved specimens of both species (observations or images of live plants being absent apart

788 from colour notes) share the following features: (1) erect very narrowly triangular to caudate

789 perianth lobes; (2) dark brown lines (corresponding with the vascular supply) extending from the

790 base of the perianth tube to the base of each perianth lobe; (3) reduced lamellae which are too

791 small to occlude the perianth tube mouth; (4) a stigma with three subulate curved-erect lobes

792 only, lacking lateral lobes. These features are shared with no other species of the genus, and may

793 be worth recognizing at the level of subgenus. Should future molecular data support generic

794 separation, these two species would comprise Oxygyne and the remaining species $O$. duncanii

795 and the three Japanese species, Saionia.

796 Oxygyne confusa Bidault, Merckx \& Byng (in Christenhusz et al. 2018: 55) was published online

797 in February 2018 while this paper was being revised. Based on the same specimen Tisserant

798 2623, this name predates Oxygyne frankei. However, because Christenhusz et al. (2018) contains

799 nearly 4000 controversial new combinations, the entire work is being considered for suppression

800 by the International Association of Plant Taxonomy under the Code as an "Opera Utique

801 Oppressa". Acceptance of the name O. confusa here would undermine the case for suppression

802 by recognising that work. However should the case to suppress the work fail, Oxygyne frankei

803 will be replaced by Oxygyne confusa because it has precedence.

804

805

806

\section{DISCUSSION}

808 Discovery and extinction 
809 The specimen Schlechter 15790 was collected in forest near Moliwe (in the eastern foothills of

810 Mt Cameroon on the Cameroonian coast of the Gulf of Guinea, Africa) in 1905, resulting in the

811 recognition and publication of Oxygyne Schltr. based on Oxygyne triandra Schltr. (Schlechter,

812 1906). This species is now believed to be extinct (Cheek \& Onana, 2011, see under species

813 account above).

814 The second collection of Oxygyne was in July 1928 in the Central African Republic

815 (C.A.R.) by Charles Tisserant (Tisserant 2623) but it was misidentified as Hydnora Thunb. (now

816 Hydnoraceae) and kept in a private collection until 1967. Consequently it was only recently

817 discovered to be an Oxygyne, described and is newly named in this paper as O. frankei Cheek.

818 The second species of Oxygyne discovered was collected (Shinzato s.n. in 1972) in

819 Japan's southern Ryukyu Islands, specifically Okinawa Island, and invalidly published as

820 Saionia shinzatoi Hatus. (Hatusima, 1975, 1976). The transfer to Oxygyne as O. shinzatoi

821 (H.Ohashi) Tsukaya was not valid until Tsukaya (2016).

822 The third species of Oxygyne discovered was collected in Japan's Shikoku Ehime

823 Prefecture (Syozi Hyodo s.n., 9 Oct 1988) and named as Oxygyne hyodoi C. Abe \& Akasawa

824 (Abe \& Akasawa 1989). This was the first application of the name Oxygyne to a Japanese

825 species. Oxygyne hyodoi is now considered extinct (see species account).

826 In October 1992, a fourth species of Oxygyne was discovered, on Mt Etinde, a sub-peak

827 of Mt Cameroon in Cameroon: Cheek 3816 (Thomas \& Cheek, 1992; Peguy et al. 2000; Cheek et

828 al., 1996; Cable \& Cheek, 1998; Cheek, 1996, 1997, 2006: Cheek \& Ndam, 1996; Cheek \&

829 Williams, 2000). It is formally described and newly named in this paper as Oxygyne duncanii. It

830 has not been re-recorded since its discovery (Sainge et al., 2017).

831 The fifth discovered species of Oxygyne, the third from Japan, was viewed by Hiroaki

832 Yamashita on the island of Yaku, South of Kyushu 24 Oct 2000, and later collected (Fuse,

833 Yamashita \& Ikeda s.n., 2008) and published as Oxygyne yamashitae Yahara \& Tsukaya

834 (Yahara \& Tsukaya 2008).

835 In terms of distance, the remarkable Central African-Japan range disjunction of Oxygyne

836 is rivalled only by a few other disjunct distributions reported within other fully

837 mycoheterotrophic genera, including an Amphi-Pacific Northern Hemisphere disjunction in

838 Thismia (Merckx and Smets, 2014). Among other achlorophyllous mycoheterophic disjuncts,

839 Geosiris Baill. (Iridaceae) has one species in Madagascar, a second in the Comoro Islands and a 
840 third species recently discovered in northern Queensland, Australia (Gray \& Low, 2017), and

841 strong disjunctions occur within genera of Triuridaceae (Rudall et al., 2016) and Corsiaceae

842 (Mennes et al., 2015).

843

\section{One genus or two?}

845 Despite the remarkably disjunct distribution of Oxygyne, our results support its retention as a

846 single genus. Hatusima (1976) contended that Oxygyne shinzatoi, the first Oxygyne discovered in

847 Japan, was generically distinct; he erected the name Saionia for his proposed new genus, with

848 the subtribal name Saioneae Hatusima to accommodate it. He distinguished Saioneae "a subtrib.

849 Oxygynearum differt perianthium fauce haud annulatum. Stamina in geniculum e lobi perianthii

850 interiores inserta." Effectively, he stated that Saionia differs from Oxygyne in lacking a perianth

851 annulus, and in the stamens being geniculate and inserted at the inner base of the perianth lobes.

852 However, in fact, both these features are present in the type species of Oxygyne (see below under

853 O. triandra).

854 Saionia was for the most part not taken up by botanical authors, who continued to use

855 Oxygyne for the Japanese species. For example, Abe \& Akasawa (1989) rejected Hatusima's

856 contention and transferred his taxon to, and placed their new species in, Oxygyne. However,

857 Ohashi (2015) proposed to resurrect Saionia for the Japanese species of Oxygyne, stating that

858 they differ from the Cameroon species in having (1) campanulate perianth, (2) bluish colour, (3)

859 patent perianth lobes, (4) deflexed stamens of which the anthers are positioned below the base of

860 the filament, (5) appendages on the style. Yet all these features, except the bluish colour of the

861 perianth, are present in the second Cameroonian species described here as $O$. duncanii. This

862 species appears closer in morphology to the Japanese species than it does to the geographically

863 close type species, O. triandra and to the species of C.A.R., O. frankei. We maintain that flower

864 colour alone is insufficient to support generic separation of the Japanese from the Cameroonian

865 taxa. In the absence of molecular data, we are also reluctant to accept inclusion of $O$. duncanii in

866 Saionia, even though it shares four of the five generic characters of Saionia.

867 Both $O$. triandra and $O$. frankei are known only from pressed specimens. Unlike all the

868 other species of Oxygyne, there is no photograph or even a preserved field sketch of either

869 species in the live state. We contend that several of the stated features of $O$. triandra (and the

870 similar, newly described, O. frankei) that are given as points of generic separation may be 
871 artefacts of preservation, the state of anthesis or errors of artistic interpretation of the single 872 known plant of $O$. triandra. For example, the first author has observed that in $O$. duncanii the 873 perianth lobes in life are patent, but that on preservation in alcohol they tend to become erect, as

874 in the drawing of Oxygyne triandra. Thus, it is entirely possible that this supposed generic 875 distinction could also be an artefact of preservation. Similarly, the position of the anther in 876 relation to the base of the declinate staminal filament can be interpreted from the drawing of $O$.

877 triandra (and in the type specimen of $O$. frankei) as being at about the same level, which, while 878 not "below the base of the filament" is very close to it. Furthermore, it is unlikely that the precise 879 position of the anther in relation to the filament base would be reliably preserved in herbarium 880 specimens, casting doubt on a second point of difference.

881

882 Are there more Oxygyne species?

883 The possibility exists that further species of Oxygyne will yet be found. If so, they might

884 be expected between SW Cameroon and Japan. However, the fact that numerous other

885 achlorophyllous species in several genera have been discovered between these locations suggests 886 that while possible, this is improbable. The reality is that additional species are most likely to be 887 found in adjoining areas to those where the existing (or previously existing) species are found, 888 namely in SW Region Cameroon, C.A.R. and in southern Japan. Yet the unexpected discovery of 889 O. frankei in gallery forest of C.A.R. confounds the previous pattern, wherein Oxygyne species 890 only occurred in high rainfall areas with high species diversity and other rare and endemic 891 species. Certainly it would be worth exploring other gallery forest areas in tropical Africa for 892 additional species. However, natural rainforest habitat, including gallery forest, is rapidly being 893 lost and degraded (M. Cheek, personal observations ). For this reason, effort is being invested to 894 evidence and demarcate the highest priority areas for plant conservation as Important Plant Areas 895 in the tropics (Darbyshire et al., 2017).

896

\section{ACKNOWLEDGEMENTS}

898 Janis Shillito typed an earlier version of the manuscript. Eimear Nic Lughadha and two 899 anonymous reviewers gave advice on an earlier version of the manuscript. James Byng first 900 mentioned to the first author an unresolved thismiaceous specimen from C.A.R.. George Gosline 901 is thanked for independently subsequently uncovering the existence of that specimen, Tisserant 
902 2623, and strongly advising that it be studied for the current paper, and for drawing Figure 1. Dr

903 Peguy Tchouto is thanked for helping to bring to light the first plant of $O$. duncanii. Josef Bogner

904 encouraged the first author to publish on Oxygyne. The late Anacletus Koufani and Joseph

905 Asonganyi (both formerly of YA), and Karen Sidwell (formerly of K and BM) are thanked for

906 their efforts in searches for Oxygyne duncanii on $25^{\text {th }}$ and $26^{\text {th }}$ October 1992. Shigeo Yasuda

907 (Yokohama) is thanked for his extensive and strenuous efforts in researching and translating the

908 Japanese literature on Oxygyne with the assistance of Prof. Koyama (Makino Botanic Garden).

909 Akiko Shimizu also kindly provided information on the literature of Oxygyne in Japan.

910

911

912 REFERENCES

913 Abe C, Akasawa Y. 1989. A new species of Oxygyne (Burmanniaceae) found in Shikoku, 914 Japan. Journal of Japanese Botany 64(6): 161-164.

915 Agardh JG. 1858. Theoria Systematis Plantarum. C.W.K. Gleerup, Lund.

916

917

Anon. 1996. Threatened Wildlife in Okinawa (second ed.). Nature Conservation Division,

918

Dept. Cultural and Environmental Affairs, Okinawa Prefectural Govt. p.111

919

Anon. 2000. The Red Data Book of Japan, Threatened Wildlife of Japan, Vascular Plants. $2^{\text {nd }}$

920

Ed. Ministry of the Environment, Japan, Tokyo. pp. 200-201.

921

Anon. 2001. Threatened plants in Kinki District, Hiraoka Envir. Sci. Lab. p.35.

922

Anon. 2003. Threatened Wildlife in Ehime. Nature Conservation Division, Dept of the

923 Environment, Ehime Prefectural Govt. p. 283.

924

925

Baker W, Hunt L, von Rege I. 1995. Mabeta-Moliwe 1993, An Oxford University Expedition

926 to Cameroon. Cyclostyled report. $24 \mathrm{pp}$.

927

Cable S, Cheek M. 1998. The Plants of Mount Cameroon, A Conservation Checklist. R.B.G., Kew, 279 pp (lxxix, 198).

928

Cheek M. 1992. A Botanical Inventory of the Mabeta-Moliwe Forest. Royal Botanic Gardens, Kew; report to Govt. Cameroon from O.D.A.

930 Cheek M. 1996. Burmanniaceae, pp. 9/258-259 in Tomoko Ishizuka (Ed.), The World of Plants, Asahi Shimbun 105 (issued 28 April 1996)

932 Cheek M. 1997. Ghosts and ghost hunters. Kew Magazine, Autumn 1997, pp 16-19. 
933 Cheek M. 2000. A synoptic revision of Ancistrocladus (Ancistrocladaceae) in Africa, with a

934

935

936

937

938

939

940

941

942

943

944

945

946

947

948

949

950

951

952

953

954

955

956

957

958

959

960

961

962 new species from western Cameroon. Kew Bulletin 55: 871-882. 116. https://doi.org/10.2307/4113632

Cheek M. 2002. Three new species of Cola (Sterculiaceae) from western Cameroon, Cameroon. Kew Bulletin 57: 402-415. https://doi.org/10.2307/4111117

Cheek M. 2004a. Kupeaeae, a new tribe of Triuridaceae from Africa. Kew Bulletin 58: 939949. https://doi.org/10.2307/4111207

Cheek M. 2004b. A new species of Afrothismia (Burmanniaceae) from Kenya. Kew Bulletin 58: 951-955. https://doi.org/10.2307/4111208

Cheek M. 2006. African Saprophytes: new discoveries in S.A. Ghazanfar, H.J. Beentje (eds). Taxonomy and Ecology of African Plants, their Conservation and Sustainable Use. Proceedings of the 17th AETFAT Congress, Addis Ababa, Ethiopia. Royal Botanic Gardens Kew. Pp 798.

Cheek M. 2007. Afrothismia amietii (Burmanniaceae), a new species from Cameroon. Kew Bulletin 61: 605-607

Cheek M. 2009. Burmanniaceae in Flora Zambesiaca 12:145-148

Cheek M, Bridson D. 2002. Two new species of Psychotria (Rubiaceae) from western Cameroon. Kew Bulletin 57: 389-395. https://doi.org/10.2307/4111114

Cheek M, Cable S. 1997. Plant Inventory for conservation management: the Kew-Earthwatch programme in Western Cameroon, 1993-96, pp. 29-38 in Doolan, S. (Ed.) African Rainforests and the Conservation of Biodiversity, Earthwatch Europe, Oxford.

Cheek M, Cable S, Hepper FN, Ndam N, Watts J. 1996. Mapping plant biodiversity on Mt. Cameroon. pp. 110-120 in van der Maesen, van der Burgt, van Medenbach de Rooy (Eds), The Biodiversity of African Plants (Proceedings XIV AETFAT Congress). Kluwer. https://doi.org/10.1007/978-94-009-0285-5_16

Cheek M, Cable S. 2000. Oxygyne triandra. The IUCN Red List of Threatened Species 2000: e.T39556A10248327. http://dx.doi.org/10.2305/IUCN.UK.2000.RLTS.T39556A1024832 7.en. Downloaded on 30 July 2017.

Cheek M, Csiba L 2002. A new epiphytic species of Impatiens (Balsaminaceae) from western Cameroon. Kew Bulletin 57: 669-674. https://doi.org/10.2307/4110997 
963 Cheek M, Etuge M. 2009. A new submontane species of Deinbollia (Sapindaceae) from

964

965

966

967

968

969

970

971

972

973

974

975

976

977

978

979

980

981

982

983

984

985

986

987

988

989

990

991

992 Western Cameroon and adjoining Nigeria. Kew Bulletin 64: 503-508. https://doi.org/10.1007/s12225-009-9132-4

Cheek M, Fischer E. 1999. A tuberous and epiphytic new species of Impatiens (Balsaminaceae) from Southwest Cameroon. Kew Bulletin 54: 471-475. https://doi.org/10.2307/4115828

Cheek M, Harvey Y, Onana JM. 2010. The plants of Dom, Bamenda Highlands, Cameroon, A Conservation Checklist, RBG, Kew, 162pp.

Cheek M, Jannerup P. 2006. A new species of Afrothismia (Burmanniaceae) from Tanzania. Kew Bulletin 60: 593-596.

Cheek M, Mackinder B, Gosline G, Onana JM, Achoundong G. 2001. The phytogeography and flora of western Cameroon and the Cross River-Sanaga River interval. Systematics and Geography of Plants 71: 1097-1100. https://doi.org/10.2307/3668742

Cheek M, Ndam N. 1996. Saprophytic Flowering Plants of Mount Cameroon pp. 612-617 in van der Maesen, van der Burgt, van Medenbach de Rooy (Eds), The Biodiversity of African Plants (Proceedings XIV AETFAT Congress). Kluwer. https://doi.org/10.1007/97894-009-0285-5 74

Cheek M, Onana J-M. 2011. Extinct species in Cameroon: Oxygyne triandra, in: Red Data Species in Cameroon, a Guide for Secondary School Teachers. Royal Botanic Gardens, Kew.

Cheek M, Pollard BJ, Darbyshire I, Onana JM, Wild C. 2004. The Plants of Kupe, Mwanenguba and the Bakossi Mts, Cameroon. A Conservation Checklist. RBG, Kew. $508 \mathrm{pp}$.

Cheek M, Radcliffe-Smith A, Faruk A. 2000. A new species of Drypetes (Euphorbiaceae) from Western Cameroon. Kew Bulletin 55: 871-882. https://doi.org/10.2307/4113635

Cheek M, Thomas D, Besong JB, Gartlan S, Hepper FN. 1994. Mount Cameroon, Cameroon pp. 163-166 in S. D. Davies, V.H. Heywood, A.C. Hamilton (eds.) Centres of Plant Diversity: A Guide and Strategy for their Conservation. WWF/IUCN. Cambridge.

Cheek M, Williams S. 2000. A Review of African Saprophytic Flowering Plants, pp. 39-49 in Timberlake, Kativu (Eds.) African Plants. Biodiversity, Taxonomy \& Uses.. Proceedings of the 15th AETFAT Congress at Harare, Zimbabwe. RBG, Kew. 581 pp. 
993 Cheek M, Williams S, Etuge M. 2003. Kupea martinetugei, a new genus and species of

994

995

996

997

998

999

1000

1001

1002

1003

1004

1005

1006

1007

1008

1009

1010

1011

1012

1013

1014

1015

1016

1017

1018

1019

1020

1021

1022

Triuridaceae from western Cameroon. Kew Bulletin 58: 225-228. https://doi.org/10.2307/4119366

Christenhusz MJM, Fay MF, Byng JW. (Eds) 2018. The Global Flora. Nomenclature Part 1, Volume 4: 1-155. Plant Gateway Ltd, Bradford, U.K.

Darbyshire I, Anderson S, Asatryan A, Byfield A, Cheek M, Clubbe C, Ghrabi Z, Harris T, Heatubun CD, Kalema J, Magassouba S, McCarthy B, Milliken W, Montmollin B de, Nic Lughadha E, Onana JM, Saıdou D, Sarbu A, Shrestha K \& Radford, EA. 2017. Important Plant Areas: revised selection criteria for a global approach to plant conservation. Biodiversity Conservation 26: 1767 - 1800. DOI 10.1007/s10531-0171336-6.

Davis PH, Heywood VH. 1963. The Principles of Angiosperm Taxonomy. Oliver \& Boyd. Edinburgh.

Franke T. 2004. Afrothismia saingei (Burmanniaceae, Thismieae), a new myco-heterotrophic plant from Cameroon. Systematics and Geography of Plants 74:27-33.

Franke T, Beenken L, Döring M, Kocyan A, Agerer R. 2006. Arbuscular mycorrhizal fungi of the Glomus-group A lineage (Glomerales' Glomeromycota) detected in mycoheterotrophic plants from tropical Africa. Mycol. Progress 5: 24-31.

Franke T, Sainge M, Agerer. 2004. A new species of Afrothismia (Burmanniaceae, tribe Thismieae) from the western foothills of Mt Cameroon. Blumea 49: 451-456; figs. 1-2.

Gomes SIF, Aguirre-Gutierrez J, Bidartondo MI, Merckx VSFT. 2016. Arbuscular mycorrhizal interactions of mycoheterotrophic Thismia are more specialized than in autotrophic plants. New Phytologist 93: 1684-1998.

Gosline G, Cheek M, Kami T. 2014. Two new African species of Salacia (Salacioideae, Celastraceae). Blumea 59: 26-32. https://doi.org/10.3767/000651914x682026

Gray B, Low YW. 2017. First record of Geosiris (Iridaceae: Geosiridoideae) from Australia: a new record and a new species from the Wet Tropics of Australia, Queensland. Candollea 2: $249-255$.

Griffith W. 1845. Thismia. Proceedings of the Linnean Society of London 1: 221. 
1023 Harvey Y, Pollard BJ, Darbyshire I, Onana JM, Cheek M. 2004. The Plants of Bali Ngemba

1024

1025

1026

1027

1028

1029

1030

1031

1032

1033

1034

1035

1036

1037

1038

1039

1040

1041

1042

1043

1044

1045

1046

1047

1048

1049

1050

1051

1052

Forest Reserve, Cameroon. A Conservation Checklist. Royal Botanic Gardens, Kew. 154 pp.

Harvey YH, Tchiengue B, Cheek M. 2010. The plants of the Lebialem highlands, A conservation checklist. RBG, Kew.

Hatusima S. 1975. Flora of the Ryukyus, added and corrected. Okinawa Association of Biology Education, Naha. (In Japanese).

Hatusima S. 1976. Two new species of Burmanniaceae from Japan. Journal of Geobotany 24: $2-6$.

Hatusima S, Amano T. 1994. Flora of the Ryukus, south of Amami Island. $2^{\text {nd }}$ Ed. The Biological Society of Okinawa.

Hatusima S, Nackejima C. 1979. Flowers of the Ryukyu Islands, Japan. Kohdansha, Tokyo

Hepper FN. 1968. Burmanniaceae, pp. 176-180 in Hepper, FN (ed) Flora of West Tropical Africa (second edition) 3(1). Crown Agents, London.

Imhof S, Massicotte HB, Melville LH, Peterson RL. 2013. Subterranean morphology and mycorrhizal structures. In: Merckx VSFT, ed. Mycoheterotrophy: The Biology of Plants Living on Fungi. Springer, 157-213.

The International Plant Names Index. 2012. www.ipni.org/ipni/ (accessed: 01/2018).IUCN 2012. IUCN Red List Categories: version 3.1. Prepared by the IUCN Species Survival Commission. IUCN, Gland, Switzerland and Cambridge, UK.

Jonker FP. 1938. A Monograph of Burmanniaceae. Utrecht.

Kato M, Ebihara A. 2011. Endemic plants of Japan. Tokai University Press, Hatano. (In Japanese).

Kauff F, Rudall PJ, Conran JG. 2000. Systematic root anatomy of Asparagales and other monocotyledons. Plant Systematics and Evolution 223: 139-154.

Kobayashi T, Kobayashi N. 1993. On a species of Oxygyne (Burmanniaceae) from Kobe City. J. Phytogeogr. \& Taxon [Shokubutsu Chiri Bunrui Kenkyu, Ishikawa] 41 (1): 29-30 (in Japanese).

Maas-van de Kamer H. 1998. Burmanniaceae in Kubitzki K. (ed.). The Family and Genera of Vascular Plants III. Monocots, Lilianae (except Orchidaceae). Springer, Berlin. 
1053 McNeill J, Barrie FR, Buck WR, Demoulin V, Greuter W, Hawksworth DL, Herendeen PS, 1054 Knapp S, Marhold K, Prado J, Prud'homme van Reine WF, Smith GF, Wiersema JH,

1055 Turland NJ. eds. 2012. International Code of Nomenclature for algae, fungi, and plants

1056 (Melbourne Code), Adopted by the Eighteenth International Botanical Congress Melbourne,

1057 Australia, July 2011 (electronic ed.). Bratislava: International Association for Plant Taxonomy.

1058 Mennes CB, Lam VKY, Rudall PJ, Lyon SP, Graham SW, Smets EF, Merckx VSFT. 2015.

1059 Ancient Gondwana break-up explains the distribution of the mycoheterotrophic family

1060 Corsiaceae (Liliales). Journal of Biogeography 42: 1123-1136.

1061 Merckx VSFT. 2008. Mycoheterotrophy in Dioscoreales. PhD Thesis. Katholieke Universiteit

1062 Leuven.

1063 Merckx VSFT, Bidartondo MI. 2008. Breakdown and delayed cospeciation in the arbuscular

1064 mycorrhizal mutualism. Proceedings of the Royal Society B. 275: 1029-1035.

1065 Merckx VSFT, Gomes SIF, Wapstra M, Hunt C, Steenbeeke G, Mennes CB, Walsh N,

1066 Smissen R, Hsieh TS, Smets EF, Bidartondo MI. 2017. The biogeographical history of

1067 the interaction between mycoheterotrophic Thismia (Thismiaceae) plants and mycorrhizal

1068 Rhizophagus (Glomeraceae) fungi. Journal of Biogeography 93: 1684-1998.

1069 Merckx VSFT, Schols P, Maas-van der Kamer H, Maas P. 2006. Phylogeny and evolution of

1070 Burmanniaceae (Dioscoreales) based on nuclear and mitochondrial data. American

1071 Journal of Botany 93: 1684-1998.

1072 Merckx VSFT, Smets EF. 2014. Thismia americana, the 101st anniversary of a botanical

1073 mystery. International Journal of Plant Sciences 175: 165-175.

1074 Ministry of the Environment, Japan. 2016. Oxygyne shinzatoi. The IUCN Red List of

1075 Threatened Species 2016:

1076

1077 e.T22486125A22486806. http://dx.doi.org/10.2305/IUCN.UK.20161.RLTS.T22486125A22486806.en. Downloaded on 30 July 2017.

Ohashi H. 2015. Resurrection of Saionia (Thismiaceae). Journal of Japanese Botany 90: 115-

1082 118 
1083 Onana JM, Cheek M. 2011. Red Data Book of the Flowering Plants of Cameroon: IUCN

1084

1085

1086

1087

1088

1089

1090

1091

1092

1093

1094

1095

1096

1097

1098

1099

1100

1101

1102

1103

1104

1105

1106

1107

1108

1109

1110

1111

Global Assessments. RBG, Kew. 578pp.

Peguy T, Edwards I, Cheek M, Ndam N, Acworth J. 2000. The Cloud Forest of Mt Cameroon, pp. 263-277 in Timberlake, Kativu (Eds.) African Plants. Biodiversity, Taxonomy \& Uses.. Proceedings of the 15th AETFAT Congress at Harare, Zimbabwe. RBG, Kew. 581 pp

Rudall PJ, Alves M, Sajo MG. 2016. Inside-out flowers of Lacandonia brasiliana (Triuridaceae) provide new insights into fundamental aspects of floral patterning. PeerJ 4:e1653; doi: 10.7717/peerj.1653

Sainge MN, Franke T, Merckx M, Onana JM. 2010. Distribution of myco-heterotrophic (saprophytic) plants of Cameroon. In van der Burgt X, van der Maesen J. Onana JM. (eds). Systematics and Conservation of African Plants, 281-288. Royal Botanic Gardens, Kew.

Sainge MN, Chuyong GB, Peterson, AT. 2017. Endemism and geographic distribution of African Thismiaceae. Plant Ecology and Evolution 150: 304312. https://doi.org/10.5091/plecevo.2017.1196

Schlechter R. 1906. Burmanniaceae africanae. Botanischer Jahrbucher 38:140-141, Fig. 1, GM.

Stevens, P. F. 2001 onwards. Angiosperm Phylogeny Website. Version 14, July 2017. http://www.mobot.org/MOBOT/research/APweb/.

Stoffelen P, Robbrecht E, Smets E. 1997. Coffea (Rubiaceae) in Cameroon: a new species and a nomen recognized as species. Belgian Journal of Botany, 129, 1: 71-76

Suetsugu K. 2017. Independent recruitment of a novel seed dispersal system by camel crickets in achlorophyllous plants. New Phytologist DOI 10.1111/nph.14859.

Suetsugu K, Fukunaga H. 2016. Lecanorchis tabugawaensis (Orchidaceae, Vanilloideae), a new mycoheterotrophic plant from Yakushima Island, Japan. Phytokeys 73: 125-135.

Suetsugu K, Shitara T, Yamawo A. 2017. Seed dispersal by ants in the fully mycoheterotrophic plant Sciaphila secundiflora (Triuridaceae). Journal of Asia-Pacific Entomology 20: 914-917. DOI 10.1016/j.aspen.2017.06.011 
1112 Thiers, B. continuously updated. Index Herbariorum: A global directory of public herbaria and

1113

1114

1115

1116

1117

1118

1119

1120

1121

1122

1123

1124

1125

1126

1127

1128

1129

1130

1131 associated staff. New York Botanical Garden's Virtual Herbarium. http://sweetgum.nybg.org/ih/ (accessed: 01/2018).

Thomas D, Cheek M. 1992. Vegetation and plant species on the south side of Mount Cameroon in the proposed Etinde reserve. Royal Botanic Gardens, Kew; report to Govt. Cameroon from ODA. 42 pp.

Tsukaya H. 2016. Burmanniaceae. In: Iwatsuki K, Boufford DE, Ohba H (Eds.) Flora of Japan, Vol. IVb. Kodansha Publisher, Tokyo, Japan, pp 194-197

Tsukaya H, Yokota M, Okada H. 2007. Chromosomal characteristics of Oxygyne shinzatoi (Hatus.) C.Abe et Akasawa (Burmanniaceae), and its phylogenetic significance. Acta Phytotax. Geobot. 58: 100-106.

Yagame T, Yamato M, Mii M, Suzuki A, Iwase K. 2007. Developmental processes of achlorophyllous orchid, Epipogium roseum: from seed germination to flowering under symbiotic cultivation with mycorrhizal fungus. Journal of Plant Research 120: 229-236.

Yahara T, Tsukaya H. 2008. Oxygyne yamashitae, a new species of Thismiaceae from Yaku island, Japan. Acta Phytotax. Geobot. 59: 97-104.

Yokoyama J, Koizumi Y, Yokota M, Tsukaya H. 2008. Phylogenetic position of Oxygyne shinzatoi (Burmanniaceae) inferred from 18S rDNA sequences. Journal of Plant Research 121: 27-32. 
Figure 1

Global distribution of the species of the African-Japanese genus Oxygyne; drawn by George Gosline.

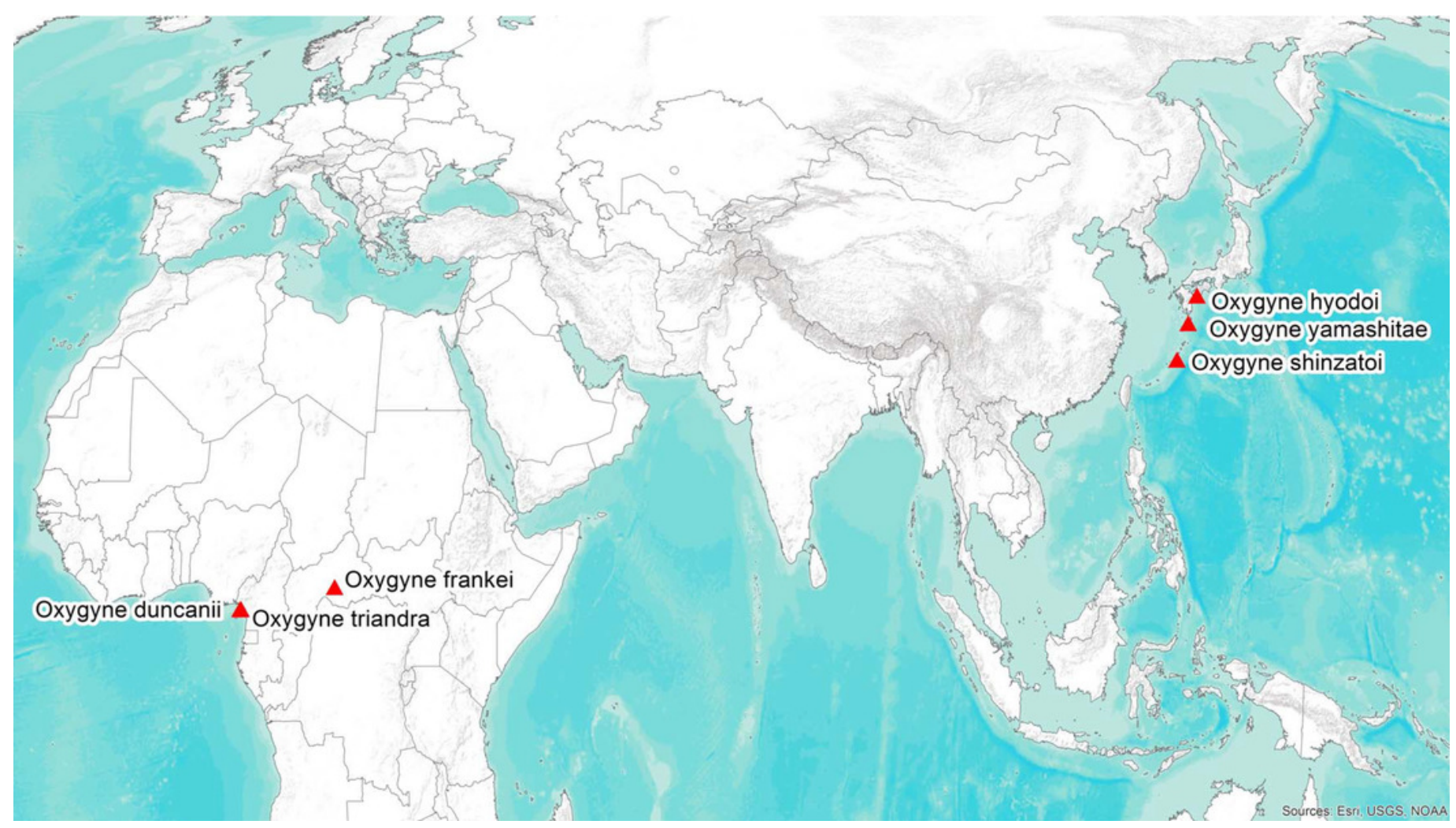




\section{Figure 2}

Phylogenetic placement of Oxygyne based on phylogeny in Yokohama et al. (2008).

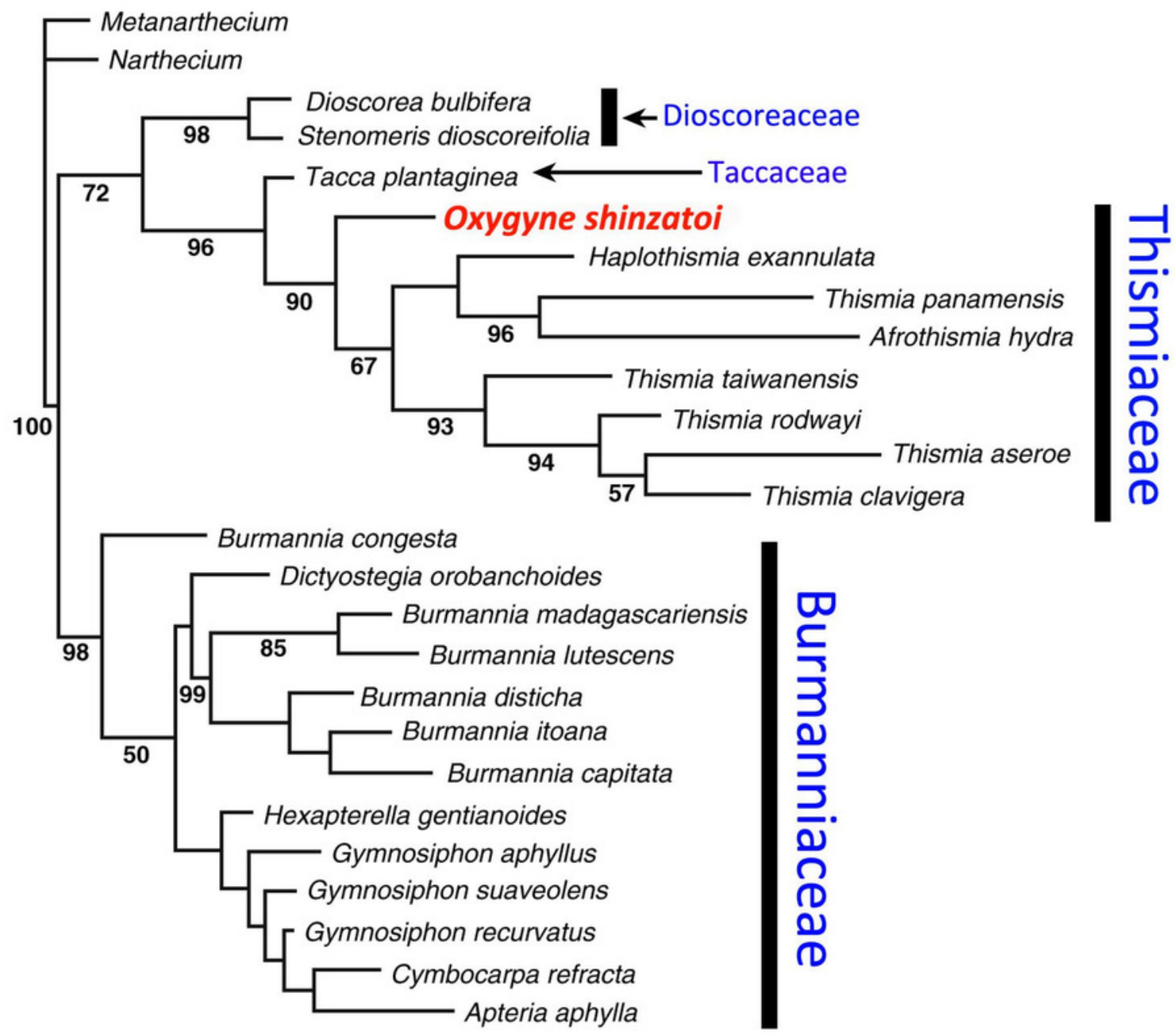


Figure 3

Oxygyne duncanii

Oxygyne duncanii, root anatomy. (A, B) Transverse sections through roots, showing central vascular strand and coils of enlarged hyphae in the cortex. (C) Longitudinal section of root showing central vascular strand and coils of hyphae in the cortex. (D) Part of root transverse section showing detail of epidermis and cortex. Labels: e, epidermis; h, hyphae; v, vascular strand. Scale bars $=100 \mu \mathrm{m}$. All photos by Paula Rudall.

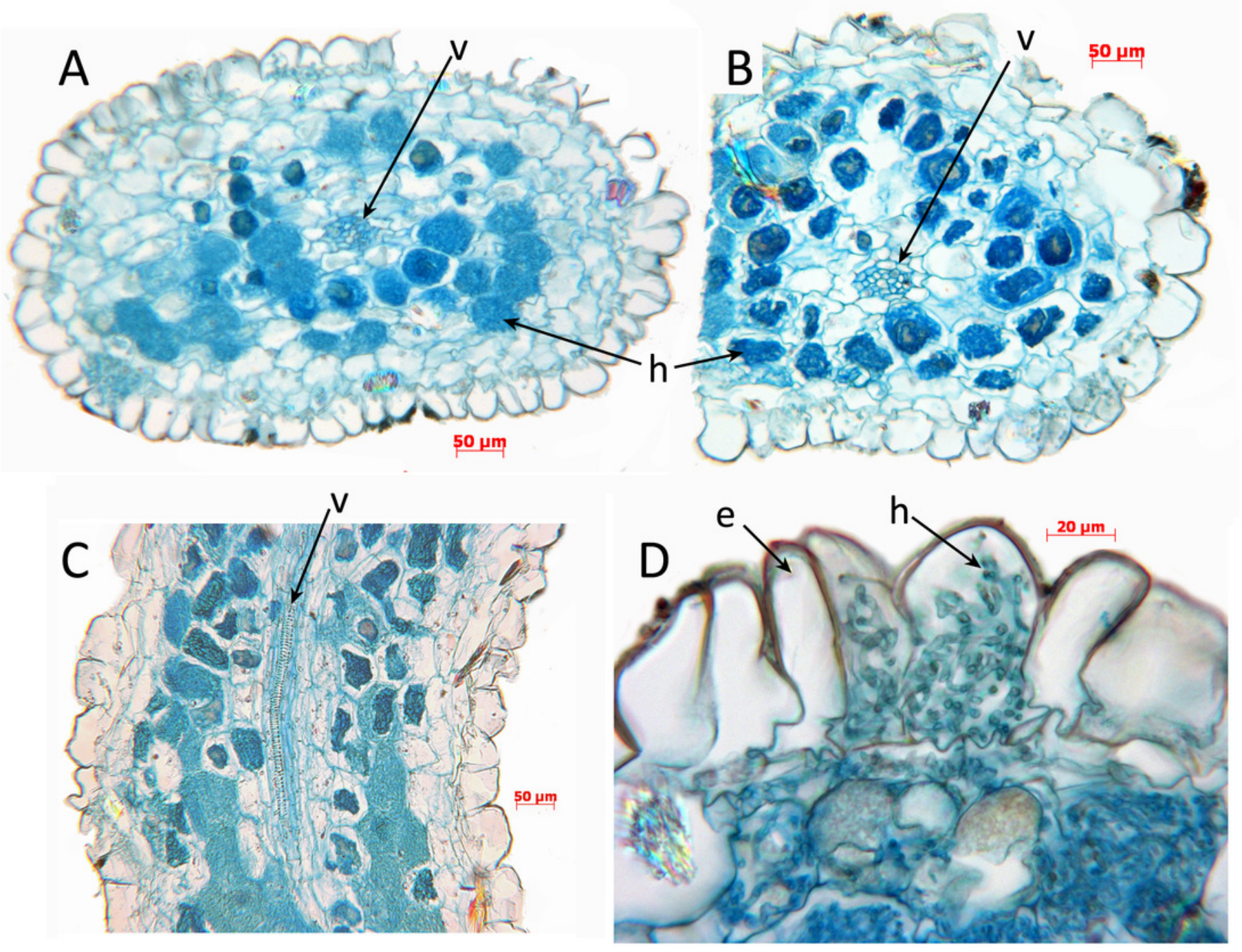




\section{Figure 4}

Oxygyne yamashitae.

(A) flower, view from above showing three stamens, each with toothed filament. (B) threequarter view of flower. (C) side view of flower, showing bracts. (D) whole plant, showing vermiform roots. All photos by Kenji Suetsugu.

*Note: Auto Gamma Correction was used for the image. This only affects the reviewing manuscript. See original source image if needed for review.
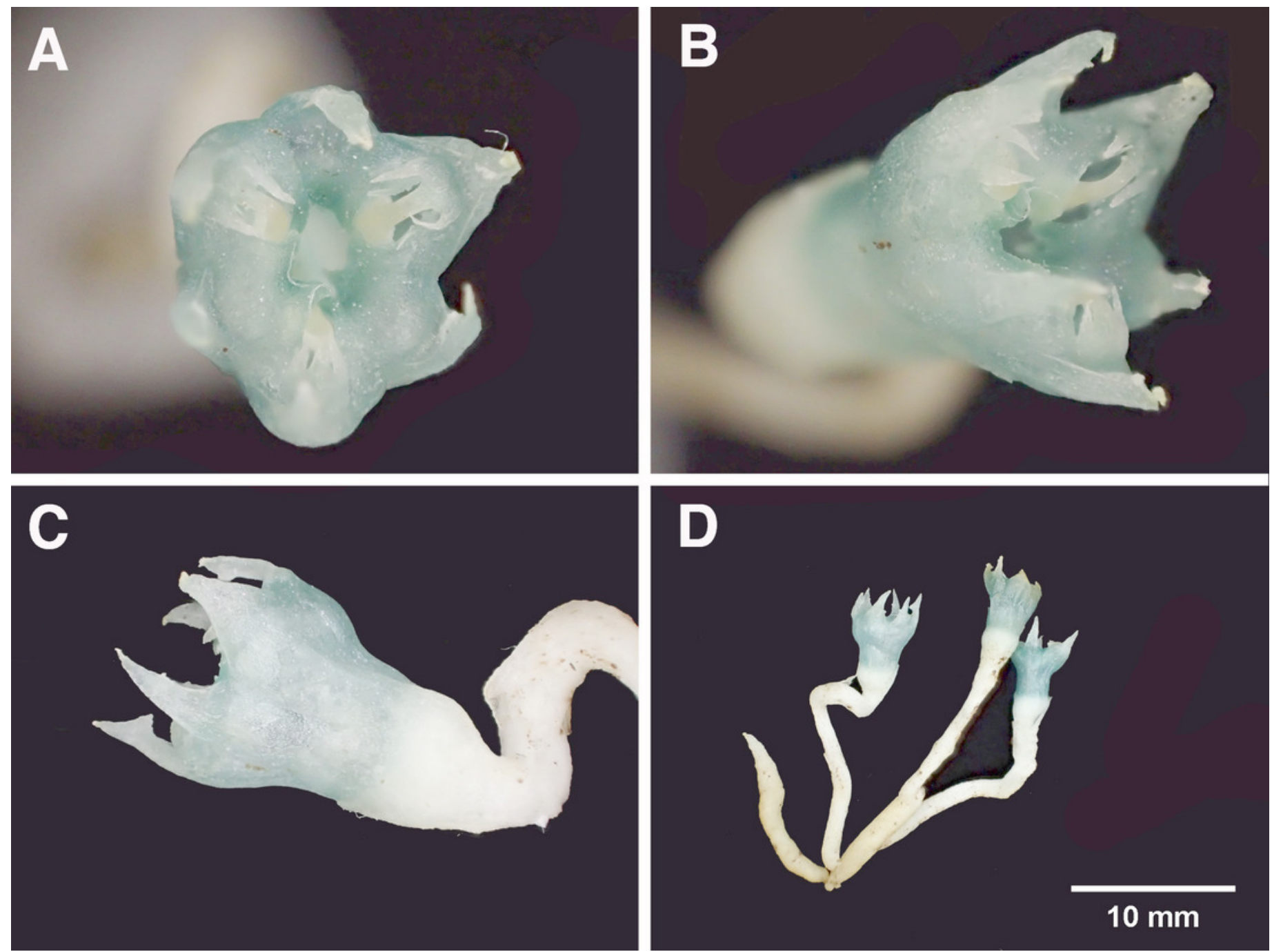


\section{Figure 5}

Oxygyne shinzatoi.

(A) cluster of flowers. (B) flower, from above. (C) flowers, fruit with shed seeds, in situ. (D) fruiting plant, side view. 24 Sept. 2008. Scale bar $5 \mathrm{~mm}$. All photos by Tazuko Watanbe.
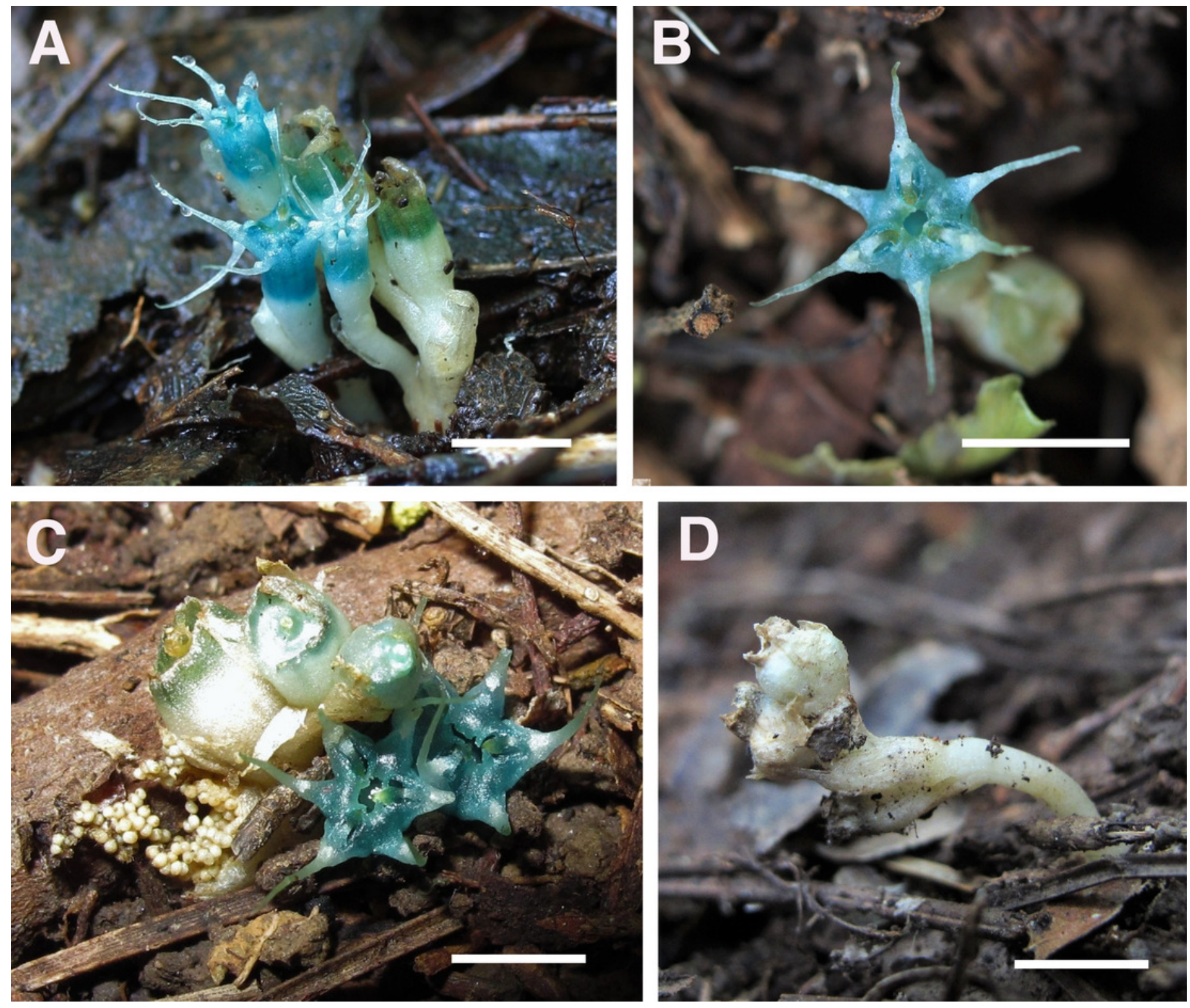


\section{Figure 6}

Oxygyne duncanii (Cheek 3816).

(A) live plant in situ, 1988 by Syozi Hyodo, scale bar $5 \mathrm{~mm}$. (B) photo of type specimen Hyodo s.n. (TI), scale bar in mm, by Kenji Suetsugu.
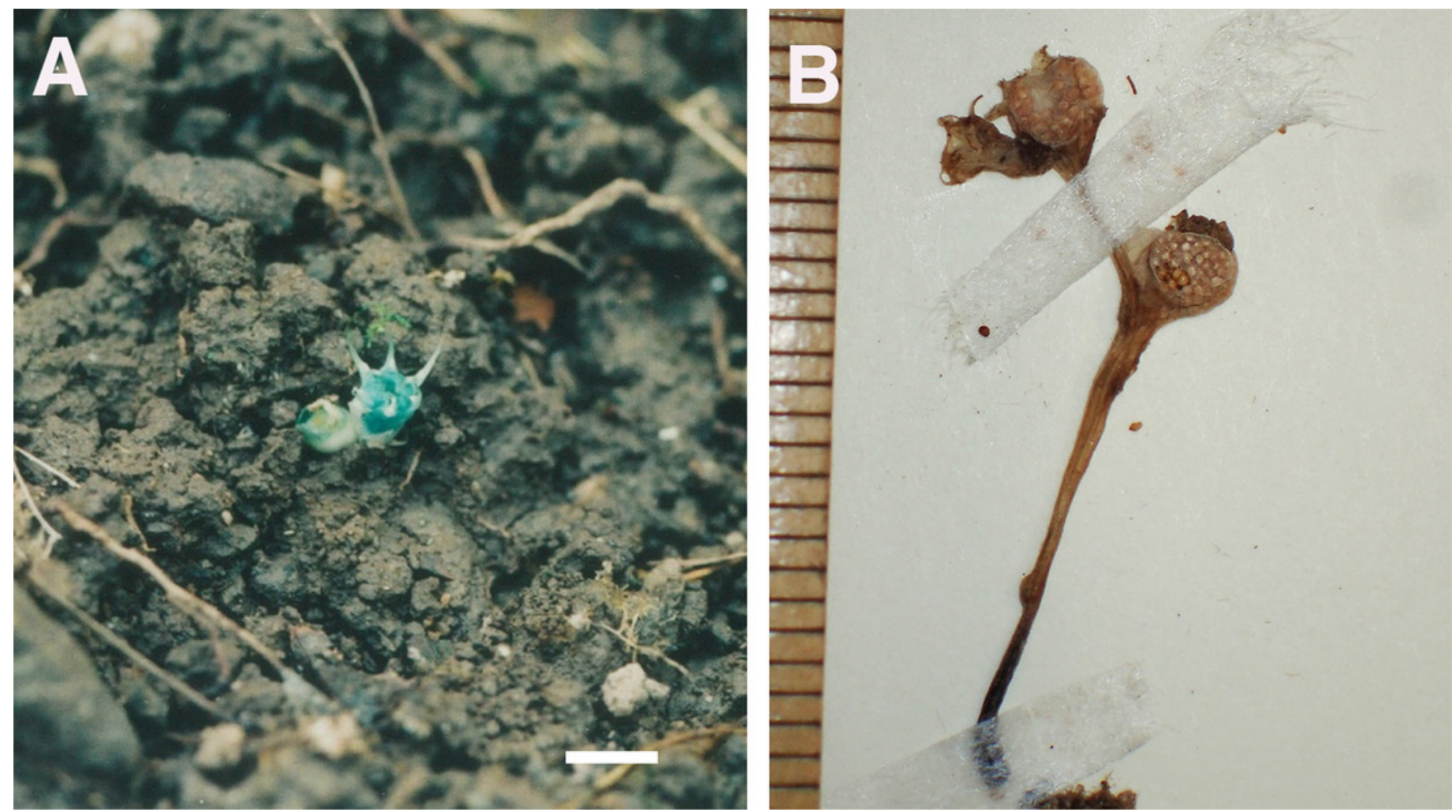
Figure 7

Oxygyne duncanii.

(A) whole plant, side view. (B) in habitat (penknife for scale). (C) close-up of flower in situ. (D) preserved specimens in ethanol. All photos by Martin Cheek.
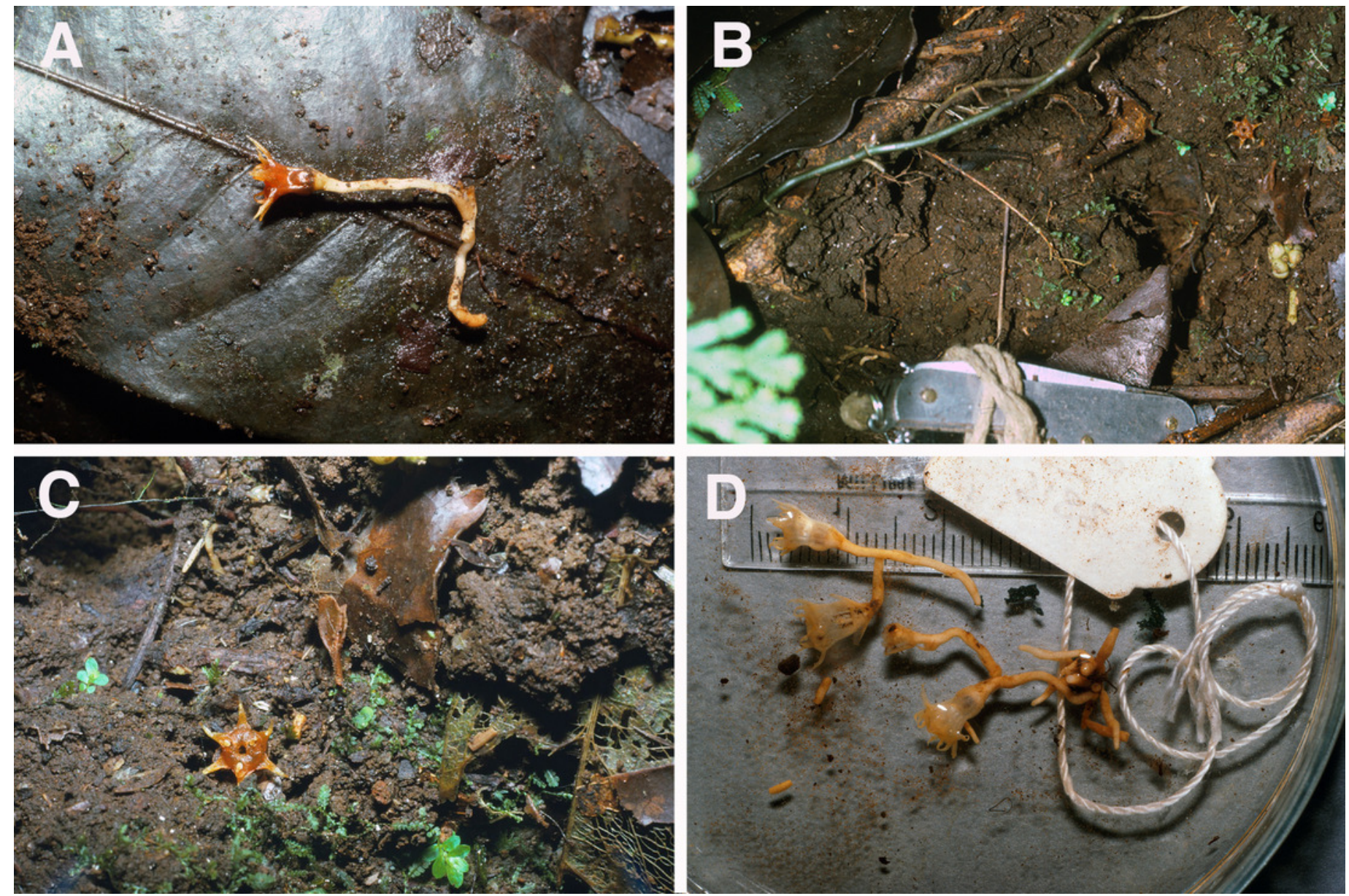


\section{Figure 8}

Oxygyne duncanii.

(A) Habit; (B) habit, whole plant exposed; (C) root branch; (D flower, sublongitudinal section;

(E) detail of mouth of the opened-out perianth tube, viewed from inside showing the annulus lamellae tightly involute as in preservation (right) and unravelled (left); (F) perianth lobe, showing adaxial mucro; $(G)$ part of stamen showing thecae on lower surface of the connective; (H) style-stigma, with disc; (I) ovary placentation, detail; (J) fruit. (A, B) from photo and from Cheek 3816, (C-H) from Cheek 3816. Drawn by Margaret Tebbs. 


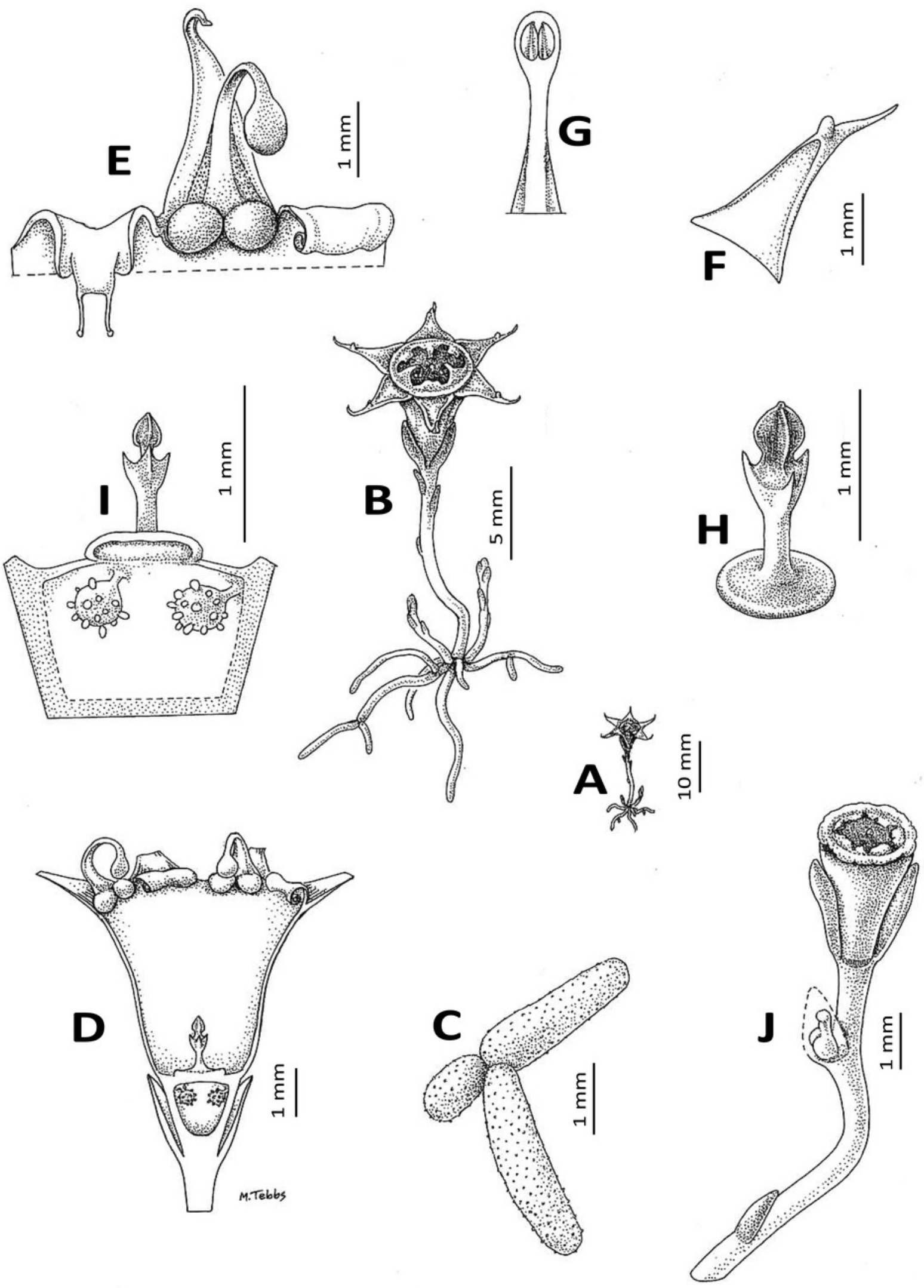


Figure 9

Oxygyne triandra.

(A) Habit. (B) flower. (C) perianth, part, opened, inner surface. (D) stamen and annulus in section, side view. (E) style-stigma. From Schlechter (1906), drawn by Joseph Pohl (18641939).
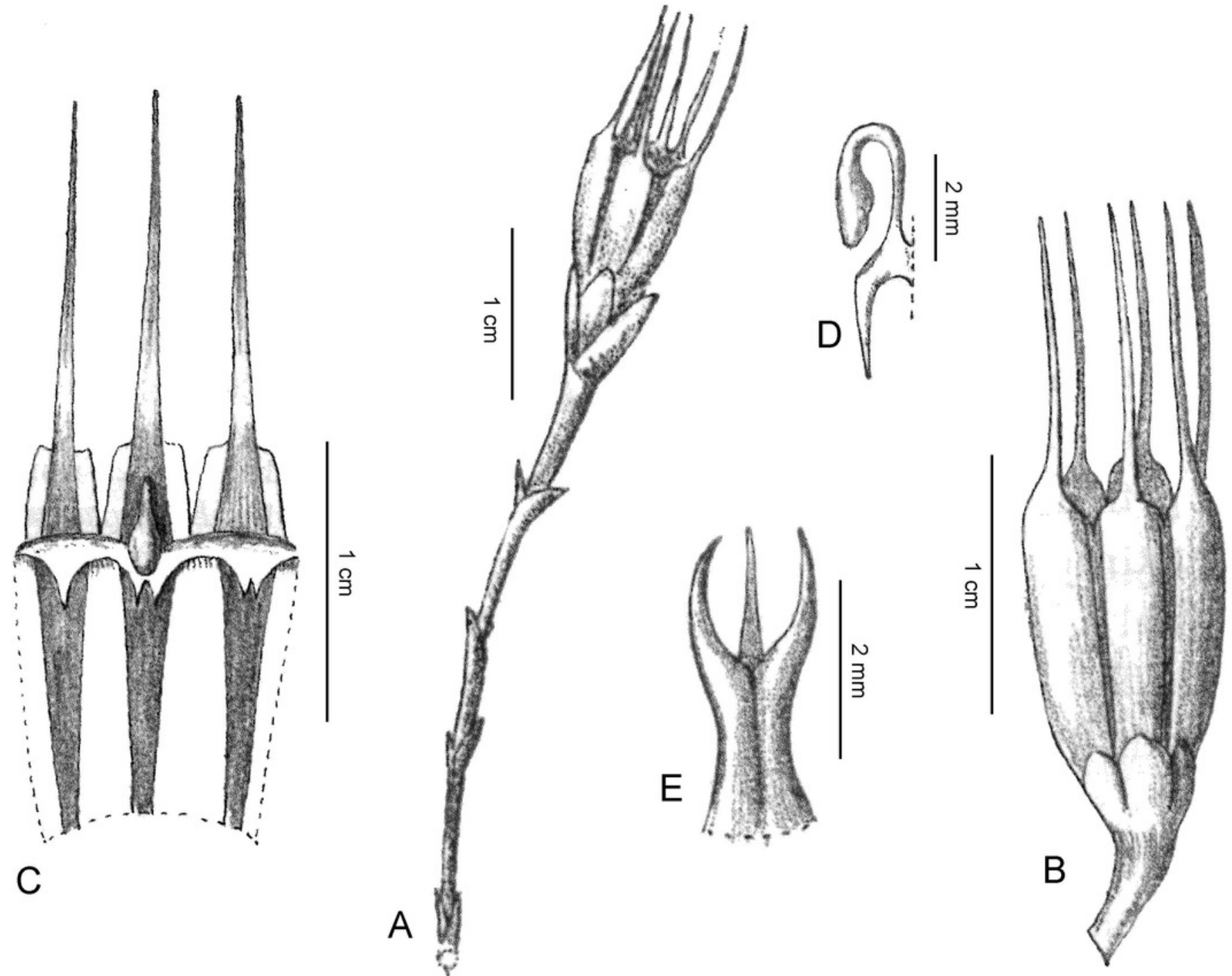


\section{Figure 10}

Oxygyne frankei.

(A) Habit, flowering plant at anthesis; (B) habit, fruiting plant with ripe seeds; (C) base of outer perianth together with base of staminal filament; (D) base of inner perianth lobe, showing the lamellum at its base; $(E)$ style and stigmas; $(F)$ stamen $(G)$ seed. $(A-G)$ from Tisserant 2623. Drawn by Martin Cheek. 

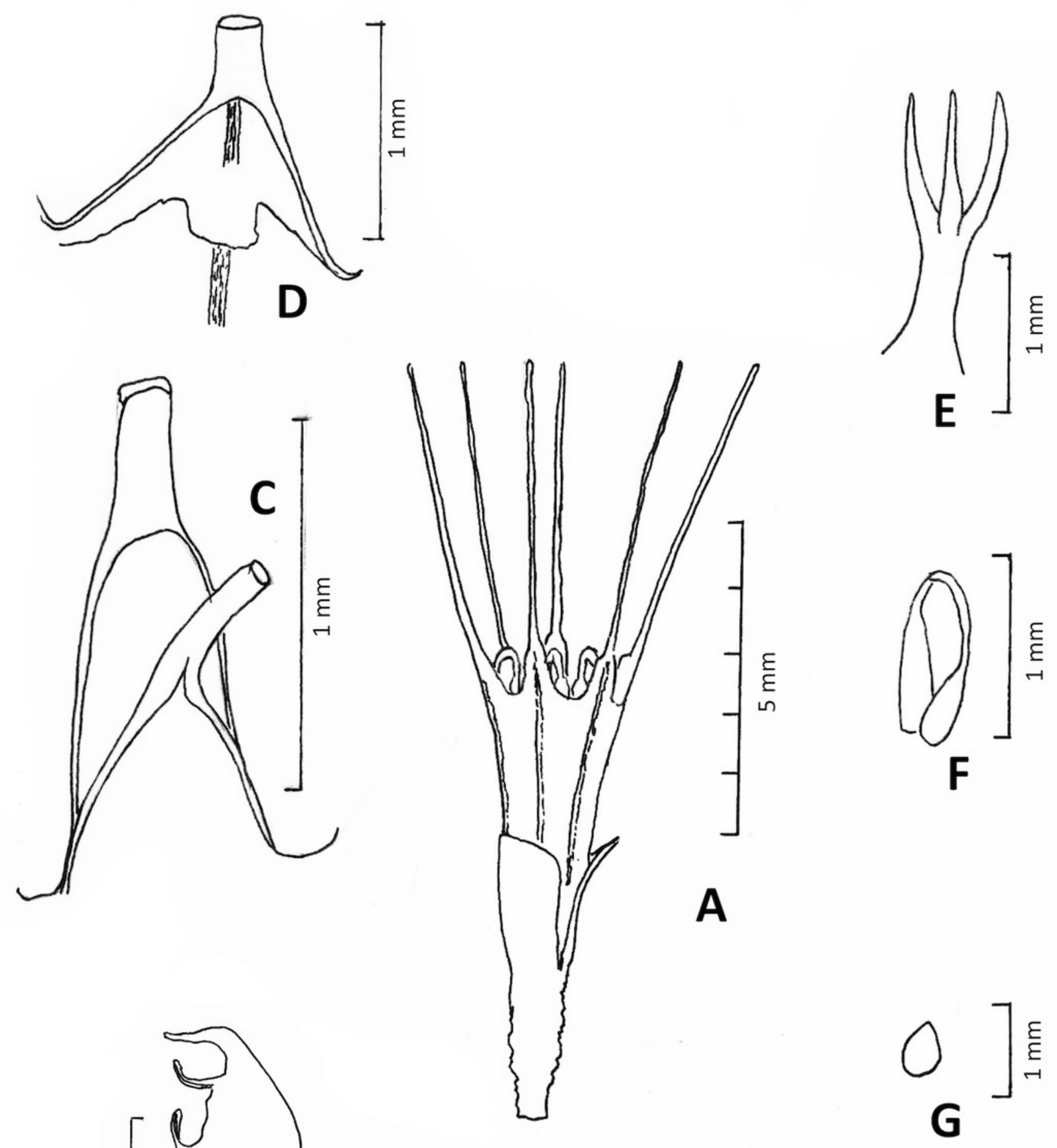